\title{
The Long Form of Fas Apoptotic Inhibitory Molecule Is Expressed Specifically in Neurons and Protects Them against Death Receptor-Triggered Apoptosis
}

\author{
Miguel F. Segura, ${ }^{1}$ Carme Sole, ${ }^{1}$ Marta Pascual, ${ }^{3}$ Rana S. Moubarak, ${ }^{2}$ M. Jose Perez-Garcia, ${ }^{1}$ Raffaella Gozzelino, ${ }^{1}$ \\ Victoria Iglesias, ${ }^{2}$ Nahuai Badiola, ${ }^{2}$ Jose R. Bayascas, ${ }^{1}$ Nuria Llecha, ${ }^{1}$ Jose Rodriguez-Alvarez, ${ }^{2}$ Eduardo Soriano, ${ }^{3}$ \\ Victor J. Yuste, ${ }^{1}$ and Joan X. Comella ${ }^{1,2}$ \\ ${ }^{1}$ Cell Signaling and Apoptosis Group, Departament de Ciències Mèdiques Bàsiques, Universitat de Lleida-Hospital Universitari Arnau de Vilanova, 25198 \\ Lleida, Spain, ${ }^{2}$ Institut de Neurociències i Departament Bioquímica i Biologia Molecular, Universitat Autònoma de Barcelona, 08193 Barcelona, Spain, and \\ ${ }^{3}$ Developmental Neurobiology and Regeneration Unit, Institute for Research in Biomedicine, Parc Cientific de Barcelona, Centro de Investigación \\ Biomédica en Red sobre Enfermedades Neurodegenerativas, and Department of Cell Biology, University of Barcelona, Barcelona 08028, Spain
}

Death receptors (DRs) and their ligands are expressed in developing nervous system. However, neurons are generally resistant to death induction through DRs and rather their activation promotes neuronal outgrowth and branching. These results suppose the existence of DRs antagonists expressed in the nervous system. Fas apoptosis inhibitory molecule $\left(\mathrm{FAIM}_{\mathrm{S}}\right)$ was first identified as a Fas antagonist in B-cells. Soon after, a longer alternative spliced isoform with unknown function was identified and named $\mathrm{FAIM}_{\mathrm{L}}$. FAIM $\mathrm{S}$ is widely expressed, including the nervous system, and we have shown previously that it promotes neuronal differentiation but it is not an anti-apoptotic molecule in this system. Here, we demonstrate that $\mathrm{FAIM}_{\mathrm{L}}$ is expressed specifically in neurons, and its expression is regulated during the development. Expression could be induced by NGF through the extracellular regulated kinase pathway in PC12 (pheochromocytoma cell line) cells. Contrary to $\mathrm{FAIM}_{S}, \mathrm{FAIM}_{\mathrm{L}}$ does not increase the neurite outgrowth induced by neurotrophins and does not interfere with nuclear factor $\kappa$ B pathway activation as $\mathrm{FAIM}_{S}$ does. Cells overexpressing $\mathrm{FAIM}_{\mathrm{L}}$ are resistant to apoptotic cell death induced by DRs such as Fas or tumor necrosis factor R1. Reduction of endogenous expression by small interfering RNA shows that endogenous $F_{A I M}$ protects primary neurons from DR-induced cell death. The detailed analysis of this antagonism shows that FAIM $_{L}$ can bind to Fas receptor and prevent the activation of the initiator caspase- 8 induced by Fas. In conclusion, our results indicate that FAIM $_{L}$ could be responsible for maintaining initiator caspases inactive after receptor engagement protecting neurons from the cytotoxic action of death ligands.

Key words: FAIM; apoptosis; Fas/CD95; TNF; neurotrophic factor; neuron

\section{Introduction}

Death receptors (DRs) and their ligands are expressed in the nervous system, particularly during development (Park et al.,

\footnotetext{
Received Sept. 22, 2006; revised Aug. 28, 2007; accepted Aug. 30, 2007.

This work was supported by Spanish Government "Ministerio de Sanidad y Consumo" (contract number PI020051, PI04/2364, Redes Temáticas de Investigación Cooperativa, and CiberNed), Fundació La Caixa (Ayudas a la Investigación en Enfermedades Neurodegenerativas 02/055-00), Ministerio de Educación y Ciencia (SAF-20050176), and Generalitat de Catalunya (Suport als Grups de Recerca Consolidats and Distinció a Joves Investigadors). M.F.S., C.S., and M.J.P.-G. were supported by a postgraduate fellowship from the Spanish Government, Ministerio de Educación y Ciencia and Fondo de Investigación Sanitaria, respectively. R.G. holds a postgraduate fellowship from the Department d'Universitat, Recerca i Societat de la Informació (Generalitat de Catalunya) and Fons Social Europeu. N.B. is the recipient of a postgraduate fellowship from the Gobierno Vasco. V.J.Y. was under a Beatriu de Pinós contract from Generalitat de Catalunya. We thank D. Trono (Geneve, Switzerland) for providing the lentiviral plasmids. We also thank Isabel Sánchez-López and Roser Pané for their expert technical assistance and Robin Rycroft for English language correction. We are grateful to Marti Aldea, Carme Gallego, and Eloi Gari from the University of Lleida for their invaluable help.

Correspondence should be addressed to Dr. Joan X. Comella, Institut de Neurociencies i Departament Bioquimica i Biologia Molecular, Universitat Autonoma de Barcelona, 08193 Cerdanyola del Valles, Barcelona, Spain. E-mail: joan.comella@uab.cat.

DOI:10.1523/JNEUROSCI.3462-07.2007

Copyright $\odot 2007$ Society for Neuroscience $\quad$ 0270-6474/07/2711228-14\$15.00/0
}

1998; Neumann et al., 2002; Shin et al., 2002; Choi and Benveniste, 2004). However, they do not seem to play a major role regulating physiological neuronal death except in certain populations such as the motoneurons (Raoul et al., 1999, 2000, 2002). The activation of DRs can alternatively induce cell survival or differentiation through the nuclear factor $\kappa \mathrm{B}(\mathrm{NF}-\kappa \mathrm{B})$ or the extracellular-regulated kinase (ERK) signaling pathways (Desbarats et al., 2003; Marchetti et al., 2004). In this way, DRs could regulate neuronal plasticity during the development of the nervous system (Cheema et al., 1999; Martin-Villalba et al., 1999; Desbarats et al., 2003; Zuliani et al., 2006). They were also involved in pathological neuronal death: Fas in spinal cord injury (Demjen et al., 2004; Yoshino et al., 2004; Casha et al., 2005; Ackery et al., 2006), or Fas and tumor necrosis factor (TNF) in axotomy-induced motoneuron death (Ugolini et al., 2003) and ischemia-induced brain damage (Martin-Villalba et al., 1999, 2001; Graham et al., 2004)

DR activity can be regulated (blocked) by anti-apoptotic proteins such as c-FLIP (FLICE-inhibitory protein), C-IAP-1/2 (cellular inhibitor of apoptosis-1/2), or the anti-apoptotic members 
of the Bcl-2 family (Liston et al., 1997; Tschopp et al., 1998; Desagher and Martinou, 2000). However, emerging evidence shows that other DR-regulatory molecules are expressed in the nervous system, such as Lifeguard (LFG) or PEA-15 (phosphoprotein enriched in astrocytes-15 kDa) (Boldin et al., 1995; Somia et al., 1999; Fernández et al., 2007).

Fas apoptosis inhibitory molecule (FAIM) was characterized as an inhibitor of Fas that was upregulated in B-cells resistant to Fas-mediated cell death (Schneider et al., 1999). Later, an alternative spliced form containing 22 aa longer at the $\mathrm{N}$ terminus was reported and named FAIM long $\left(\right.$ FAIM $_{\mathrm{L}}$ ) (Zhong et al., 2001). FAIM $_{S}$ is widely expressed, whereas FAIM ${ }_{\mathrm{L}}$ is almost exclusively expressed in the nervous system. We reported previously that FAIM $_{S}$, but not FAIM ${ }_{\mathrm{L}}$, overexpression greatly enhances neurite outgrowth in PC12 (pheochromocytoma cell line) cells and primary neurons through the NF- $\kappa \mathrm{B}$ and mitogen-activated protein kinase (MAPK)/ERK pathways (Sole et al., 2004). Nonetheless, the physiological role of FAIM $_{\mathrm{L}}$ remains so far to be elucidated.

Here, we provide for the first time evidence that FAIM $_{\mathrm{L}}$ in vivo is highly expressed by neurons in diverse areas of the brain. Moreover, FAIM $_{\mathrm{L}}$ levels are regulated during neuronal differentiation, both in vivo and in vitro, and the ERK pathway seems to be an important regulator of its expression after NGF stimulation. Ectopically overexpressed FAIM ${ }_{\mathrm{L}}$ blocks Fas and TNF-induced cell death in both PC12 cells and cortical neurons. Specific knockdown of endogenous FAIM $_{\mathrm{L}}$ transcript renders PC12 cells and primary neurons (cortical neurons and motoneurons) sensitive to the proapoptotic action of FasL and TNF- $\alpha$. FAIM ${ }_{L}$, but not FAIM $_{S}$, is able to bind nonstimulated Fas in coimmunoprecipitation experiments. Binding could be displaced by FASassociated death domain (FADD) overexpression, indicating that FAIM $_{\mathrm{L}}$ and FADD compete for Fas binding. When Fas is stimulated by FasL, the interaction between Fas and FAIM $_{\mathrm{L}}$ is no longer observed. Altogether, our results place $\mathrm{FAIM}_{\mathrm{L}}$ as a novel endogenous antagonist regulating DR-mediated neuronal cell death.

\section{Materials and Methods}

Reagents. Purified recombinant human NGF was obtained from Genentech (San Francisco, CA), and mouse 7S NGF was prepared from male submandibular salivary glands as described previously (Mobley et al., 1976). Anti-phospho-ERK1/2 was obtained from Cell Signaling Technology (Beverly, MA). Anti-pan-ERK was obtained from BD Transduction Laboratories (San Diego, CA). Anti-FLAG M2, apoptosis-inducing factor (AIF), and $\alpha$-tubulin were obtained from Sigma (St. Louis, MO). Anti- histone H1 was obtained from Stressgen (Ann Arbor, MI). Anti-Fas was obtained from Santa Cruz Biotechnology (Santa Cruz, CA). A rabbit polyclonal anti-FAIM antibody was characterized previously in our laboratory (Sole et al., 2004). All biochemicals were obtained from SigmaAldrich unless otherwise indicated.

Cell culture. PC12 cells were cultured in DMEM supplemented with $6 \%$ heat-inactivated fetal calf serum, $6 \%$ heat-inactivated horse serum (HS) (Invitrogen, Paisley, UK), 10 mM HEPES, $20 \mathrm{U} / \mathrm{ml}$ penicillin, and 20 $\mu \mathrm{g} / \mathrm{ml}$ streptomycin.

Primary cortical neurons were dissected from embryonic day 16 (E16) mice (unless otherwise indicated) and cultured as described previously (Iglesias et al., 2003). Cells were plated in $10 \mu \mathrm{g} / \mathrm{ml}$ poly-D-lysine-coated culture plates and cultured in DMEM supplemented with $10 \%$ HS. After $4 \mathrm{~h}$, medium was replaced with serum-free DMEM supplemented with B27 (Invitrogen) and N2 (Invitrogen).

Spinal cord motoneurons (MTNs) were purified from E12.5 mice according to Arce et al. (1998) and Comella et al. (1994), with minor modifications. Briefly, spinal cords were dissected from mouse embryo, trypsinized (Sigma) for $7 \mathrm{~min}$ at $37^{\circ} \mathrm{C}$, and dissociated and collected under a bovine serum albumin (BSA) cushion. The MTNs were then isolated by OptiPrep density gradient centrifugation $(10 \mathrm{~min}$ at $520 \times \mathrm{g})$.
After a final centrifugation through a BSA cushion, MTNs were resuspended in neurobasal medium supplemented with $2 \%$ horse serum, B27, $0.5 \mathrm{~mm} \mathrm{~L}$-glutamine, $25 \mu \mathrm{M}$ 2-mercaptoetanol, and $10 \mathrm{ng} / \mathrm{ml}$ BDNF (Alomone Labs, Jerusalem, Israel) and plated in poly-ornithine/laminincoated four-well plates (Nunc, Rochester, NY) at a density of $5 \times 10^{3}$ $1 \times 10^{4}$ cells per well. All cultures were maintained at $37^{\circ} \mathrm{C}$ in a saturated humidified atmosphere of $95 \%$ air and $5 \% \mathrm{CO}_{2}$.

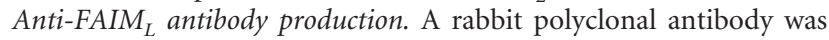
generated according to standard protocols (Harlow, 1988). The immunogenic peptide used was SGDDSPIFEDDESPLC (amino acids 3-18) and corresponds to a part of the differential sequence between FAIM $_{L}$ and FAIM $_{\mathrm{S}}$ isoforms.

Plasmids. Rat FAIM $_{\mathrm{L}}$ was expressed under the control of a cytomegalovirus constitutive promoter in the pcDNA3 expression vector (Invitrogen) as described previously (Sole et al., 2004). cDNAs containing ORFs of FADD, and murine Fas were subcloned into a vector holding a C-terminal hemaglutinin epitope (HA) or pcDNA3, respectively.

For RNA interference (RNAi) experiments, constructs were obtained into the pSUPER.retro.puro plasmid (OligoEngine, Seattle, WA) using specific oligonucleotides of the FAIM sequence, indicated by capital letter, as follows, RNAi ${ }^{\circ} 1$, which is specific for $\mathrm{FAIM}_{\mathrm{L}}$ (forward), gatccccGATGTTCAAATTGGTGGGCttcaagagaGCCCACCAATTTGAACATCttttt, and (reverse) agctaaaaaGATGTCAAATTGGTGGGCtctcttgaaGCCCACCAATTTGAACATCggg. RNAi $\mathrm{n}^{\circ} 2$, which is specific for FAIM $_{S}$ (forward), gatccccGGCAAACGAGTTGTGTACGttcaagagaCGTACACAACTCGTTTGCCttttt, (reverse) agctaaaaaGGCAAACGAGTTGTGTACGtctcttgaaCGTACACAACTCGTTTGCCggg. Oligonucleotides were obtained from Sigma and were cloned between BglII/HindIII sites of pSUPER.retro.puro plasmid. Lentiviral constructs were achieved by digesting EcoR1-ClaI sites from pSUPER-sh to replace $\mathrm{H} 1$ promoter with $\mathrm{H} 1$-shRNA cassette in pLVTHM.

Production of lentiviral particle. Lentiviruses were propagated using methods described previously (Naldini et al., 1996; Zufferey et al., 1998). Briefly, human embryonic kidney 293T (HEK293T) cells were seeded at a density of $2.5 \times 10^{6}$ cells in $0.1 \%$ gelatin-coated $100 \mathrm{~mm}$ dishes. The following day, cells were transfected with $20 \mu \mathrm{g}$ of pLVTHM or pWPI derived constructs, $13 \mu \mathrm{g}$ of pSPAX2, and $7 \mu \mathrm{g}$ of pM2G. The transfection was routinely performed by the calcium phosphate transfection method (Cullen, 1987). Cells were allowed to produce lentiviruses for $48 \mathrm{~h}$. After $48 \mathrm{~h}$, the medium was centrifuged at $1200 \times g$ for $5 \mathrm{~min}$, and the supernatant was filtered using $45 \mu \mathrm{m}$ filters. Lentiviruses were concentrated at 50,000 $\times g$ for $90 \mathrm{~min}$ and then resuspended in $20 \mu \mathrm{l}$ of PBS containing $1 \%$ BSA. Lentiviruses were stored at $-80^{\circ} \mathrm{C}$. Biological titers of the viral preparations expressed as a number of transducing units per milliliter $(\mathrm{TU} / \mathrm{ml})$ were determined by transducing HEK293T cells in limiting dilutions. After $48 \mathrm{~h}$ of incubation, the percentage of green fluorescent protein (GFP)-positive cells was counted and viruses at $5 \times$ $10^{8}-1 \times 10^{9} \mathrm{TU} / \mathrm{ml}$ were used in the experiments.

Cell transfection and transduction. Unless otherwise indicated, PC12 cells were transfected with the desired expression plasmid using Lipofectamine 2000 (Invitrogen) according to suggested manufacturer procedures. Pools of cells transfected with $\mathrm{FAIM}_{\mathrm{L}}, \mathrm{FAIM}_{\mathrm{S}}$, or empty pcDNA3 were obtained by adding $500 \mu \mathrm{g} / \mathrm{ml} \mathrm{G418} \mathrm{(Geneticin)} \mathrm{to} \mathrm{the}$ culture medium (Invitrogen).

For lentiviral-based knock-down experiments, cells were seeded in 24-multiwell plates at a density of $2 \times 10^{4}$ cells/well for PC12 cells, $1 \times$ $10^{5}$ for cortical neurons, or $5-10 \times 10^{3}$ for MTNs. Concentrated lentiviruses were added to the medium (minimum multiplicity of infection, 5). After $4 \mathrm{~h}$, the medium was changed and the infection efficiency was monitored in each experiment by direct counting of GFP-positive cells. The percentage of infection reached to $80 \%$ for cortical neurons [ $3 \mathrm{~d}$ in vitro (DIV)] and MTNs (5DIV) and 99\% for PC12 cells.

Western blot analysis. Cells were rinsed in ice-cold PBS, pH 7.2, after stimulation. Cell lysate was harvested with $2 \%$ SDS- 125 mm Tris/HCl, pH 6.8, and protein concentration was quantified by a modified Lowry assay (Bio-RadDc protein assay; Bio-Rad, Hercules, CA). Cell lysates (10-25 $\mu \mathrm{g}$ of protein) were resolved in SDS-PAGE and transferred onto polyvinylidene difluoride (PVDF) Immobilon-P membranes (Millipore, 
Bedford, MA) using a semidry transfer unit (Hoefer Pharmacia Biotech, San Francisco, CA). After blocking with Tris-buffered saline with Tween-20 containing 5\% nonfat dry milk for $1 \mathrm{~h}$ at room temperature, the membranes were probed with the appropriate primary antibodies according to the specific requirements indicated by each provider. After $1 \mathrm{~h}$ of incubation with the specific peroxidase-conjugated secondary antibodies, the membranes were developed with the EZ-ECL chemiluminescence detection kit (Biological Industries, Kibbutz Beit Haemek, Israel).

Reverse transcription-PCR analysis. Reverse transcription (RT)-PCR was essentially performed using standard protocols (Bayascas et al., 2004). Briefly, cDNA was reverse-transcribed from RNA of adult mice tissues and PC12 cells with the RNeasy kit according to the manufactured instructions (Qiagen, Valencia, CA). PCR was performed by amplification of FAIM $_{L}$, FAIM $_{S}$, and the housekeeping L27 ribosomal protein cDNAs in a PerkinElmer (Emeryville, CA) thermal cycler 2400. Primers used to amplify 189 and $246 \mathrm{bp}$ specific fragments corresponding to FAIM $_{\mathrm{S}}$ and FAIM $_{\mathrm{L}}$, respectively, were: GACAGCTGCTGACTACGTCG (forward) and TCCTTCCCATCCACGTACAC (reverse). Primers used to specifically amplify the $246 \mathrm{bp}$ fragment corresponding to FAIM $_{\mathrm{L}}$ were: CGGGATCCCTGGCGTCTGGAGATGACAGT (forward) and TCCTTCCCATCCACGTACAC (reverse). L27 primers were: AGCTGTCATCGTGAAGAA (forward) and CTTGGCGATCTTCTTCTTGCC (reverse).

Immunofluorescence. E15 cortical neurons at 1 DIV were transfected with pcDNA3-FAIM $\mathrm{L}_{\mathrm{L}}$ using Lipofectamine 2000 (Invitrogen) with the desired constructs and $48 \mathrm{~h}$ later were rinsed with PBS at room temperature and fixed in $4 \%$ paraformaldehyde/PBS for $30 \mathrm{~min}$ at room temperature. Then, they were washed twice with PBS and subsequently permeabilized and blocked with $5 \%$ bovine serum albumin and $0.1 \%$ Triton $\mathrm{X}-100$ in PBS for $60 \mathrm{~min}$ at room temperature. The cells were incubated overnight with monoclonal anti-FLAG, rinsed three times with PBS, and incubated with anti-rabbit secondary antibodies conjugated with Alexa Fluor 488 (Invitrogen, Eugene OR) for $1 \mathrm{~h}$ at room temperature protected from light. Confocal micrographs were obtained using an inverted Olympus XT FV500 microscope (Olympus Optical, Tokyo, Japan).

For the active caspase- 3 immunofluorescence, cells were fixed and permeabilized as indicated above and then incubated overnight at $4^{\circ} \mathrm{C}$ with a polyclonal anti-cleaved Caspase-3 (Cell Signaling Technology) diluted 1:150, rinsed three times with PBS, and incubated with antirabbit secondary antibodies conjugated with Alexa Fluor 594 (Invitrogen) diluted 1:250 for $1 \mathrm{~h}$ at room temperature protected from light. Finally, cells were stained with $0.05 \mu \mathrm{g} / \mathrm{ml}$ Hoechst 33258 for $30 \mathrm{~min}$. Representative micrographs were obtained using an inverted Olympus XT.

Immunohistochemistry. E16, E18, postnatal day 0 (P0), P5, P10, and adult (P60) OF-1 mice (Charles River, Lyon, France) were used for the immunohistochemistry experiments. The day when the vaginal plug was detected was considered E0 and the day of birth as P0. First, the animals were deeply anesthetized with a mixture of Ketolar (Parke-Davies/Pfizer New York, NY)/Rompun (Bayer, Leverkusen, Germany) and perfused with $4 \%$ paraformaldehyde. The brains were removed, cryoprotected, and frozen. Thirty to $50 \mu \mathrm{m}$ coronal sections were obtained. After blocking, sections were incubated overnight with specific rabbit antibody against FAIM $_{L}$ (1:600). This primary antibody was visualized by sequential incubation with biotinylated secondary antibodies (1:200; Vector Laboratories, Burlingame, CA) and the streptavidine-peroxidase complex (1:400; Amersham Biosciences, Pittsburgh, PA). The peroxidase reaction was developed with diaminobenzidine and $\mathrm{H}_{2} \mathrm{O}_{2}$. Sections were mounted onto gelatinized slides, dehydrated, and coverslipped with DPX (a mixture of distyrene, tricresyl phosphate, and xylene).

Sections from E16, P5, and adult mice were used for double immunofluorescence studies. After blocking, sections were incubated overnight with the specific rabbit antibody detecting $\operatorname{FAIM}_{\mathrm{L}}(1: 600)$ combined with mouse monoclonal antibodies against neuronal-specific nuclear protein (NeuN) (1:100; Chemicon, Temecula, CA), calbindin, or parvalbumin (Calb 1:5000; Parv, 1:2000; Swant, Bellinzona, Switzerland), GFAP (1: 500; Chemicon), or with a rat monoclonal antibody against CD31 (1:10; BD PharMingen, San Diego, CA). Primary antibodies were visualized using secondary Alexa Fluor-conjugated antibodies. Sections were counterstained with Bisbenzimide, mounted onto slides, and viewed under confocal microscopy. Some sections were also incubated with preimmune serum (1:600) and processed as above.

FAIM promoter assay. The predicted promoter of FAIM was amplified from rat genomic DNA using the primers $5^{\prime}$-TCCCCCGGGCTCTGCCAAACACCCTGATTTG-3' (forward) and 5'-CCGCTCGAGCCCAGCCTCCTACTGCCTTCC-3' (reverse). The amplified fragment (2.2 kbp) was subcloned into pGL3-basic (Promega, Mannheim, Germany). For the assay, PC12 cells were seeded into 24 -well plates and transfected with the pGL3-empty or pGL3-2.2 kbp vectors. Twenty-four hours later, cells were treated as indicated. After an additional $24 \mathrm{~h}$, cells were lysed with the Cell Culture Lysis Reagent (Luciferase Assay System Kit; Promega). The activity of firefly luciferase was determined using a FB12 Luminometer (Berthold, Bundoora, Australia). Aliquots of supernatant were transferred to a standard 96-well plate for protein concentration determination by the Lowry method (Bio-Rad) following the manufacturer instructions. Luciferase values were normalized in respect to protein concentration (RLU/ $\mu \mathrm{g}$ of protein).

Assessment of cell survival and apoptotic cell death. A total of $1 \times 10^{6}$ PC12 cells were infected with lentivirus carrying indicated constructs and $48 \mathrm{~h}$ later were split in 24 -well plates $\left(2 \times 10^{4}\right.$ cells/well $)$ in triplicate. Twenty hours later, cells were treated with sFasL (100 ng/ml), TNF $\alpha(100$ $\mathrm{ng} / \mathrm{ml}$ ) plus $1 \mathrm{~nm}$ ActD for $24 \mathrm{~h}$, or left untreated. For mouse primary cultures, neurons were transduced as described above and treated with Jo2 $(5 \mu \mathrm{g} / \mathrm{ml})$ at 3 DIV for cortical neurons and 5 DIV for motoneurons. Apoptotic cell death was measured $24 \mathrm{~h}$ later by counting apoptotic nuclei after Hoechst 33258 nuclear staining according to Yuste et al. (2005). Experiments were repeated at least three times, and a minimum of 500 cells were counted per condition. Apoptosis was also assessed by TUNEL staining. To this end, cells were fixed in $4 \%$ paraformaldehyde/ PBS for $60 \mathrm{~min}$ at room temperature, permeabilized with $0.1 \%$ Triton $\mathrm{X}-100$ in $0.1 \%$ Sodium Citrate for $2 \mathrm{~min}$ at $4^{\circ} \mathrm{C}$, and processed following the In Situ Cell Death Detection Kit instructions (Roche Products, Welwyn Garden City, UK). For the final step, Hoechst 33258 was added at $0.05 \mu \mathrm{g} / \mathrm{ml}$. The cell death was scored by counting positively stained apoptotic nuclei using an Olympus microscope equipped with epifluorescence optics. When necessary, cell viability was determined by the alamarBlue assay following the manufacturer instructions (Biosource, Camarillo, CA).

Fluorogenic caspase activities. Caspase activity determination was performed as described previously (Yuste et al., 2001). The assays were performed using $150 \mu \mathrm{M}$ fluorogenic substrate Ac-IETD-afc (caspase-8directed activities) or $50 \mu \mathrm{M}$ Ac-DEVD-afc (caspase-3-like activities). The plates were read in a Bio-Tek (Izasa, Spain) FLx800 Fluorimeter using a $360 \mathrm{~nm}$ ( $40 \mathrm{~nm}$ bandwidth) excitation filter and a $530 \mathrm{~nm}(25 \mathrm{~nm}$ bandwidth) emission filter.

Neurite measurement. PC12 cells were infected with lentivirus RS, R1, and $\mathrm{R} 2$ for $72 \mathrm{~h}$ and then washed and transferred to poly-D-lysine/ collagen-coated $35 \mathrm{~mm}$ dishes at a density of $1 \times 10^{5}$ cells per dish. Twenty-four hours later, complete medium was replaced with medium containing NGF (100 ng/ml) with $0.5 \%$ of horse serum. Photographs of random fields were taken $1 \mathrm{~d}$ later by using an inverted microscope (Olympus) equipped with epifluorescence optics coupled with a digital camera (OM-4 Ti; Olympus). Neurite outgrowth was measured using the Adobe Photoshop 6.0 software (Adobe Systems, San Jose, CA). In every experiment, a minimum of 100 cells were measured per condition.

$N F-\kappa B$ activity. NF- $\kappa$ B activity was measured as described previously (Sole et al., 2004). Briefly, PC12 cells were seeded in 24-well plates at a density of $1 \times 10^{5}$ cells/well. Cells were transfected with $0.5 \mu \mathrm{g} /$ well of the NF-kB-dependent reporter vector (HIV-LTR-Luciferase). Twenty four hours later, cells were stimulated with $100 \mathrm{ng} / \mathrm{ml} \mathrm{NGF}$ for $6 \mathrm{~h}$. The activity of firefly luciferase was determined as described above. The NF$\mathrm{kB}$-dependent reporter vector (HIV-LTR-luciferase) was obtained from R. Hay (University of St Andrews, Fife, Scotland).

Coimmunoprecipitation. For coimmunoprecipitation (CoIP) experiments, $3 \times 10^{6}$ HEK293T cells were seeded on $150 \mathrm{~mm}$ tissue culture dishes and transfected using the calcium phosphate method (Cullen,

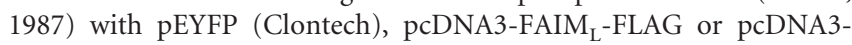




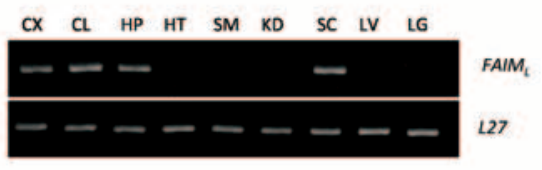

A

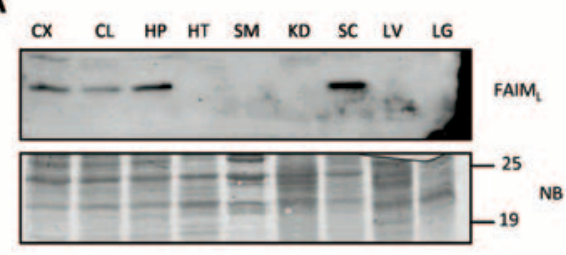

B

C

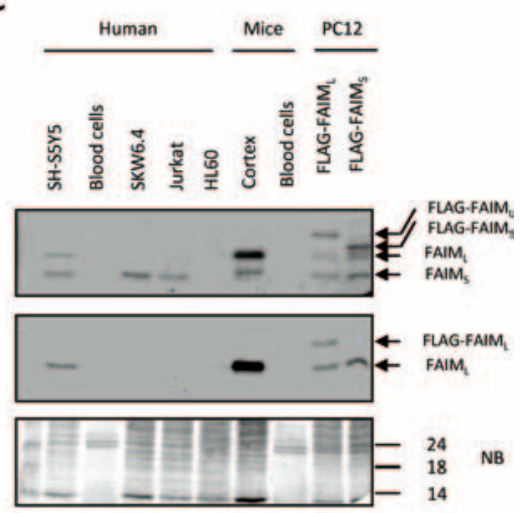

D

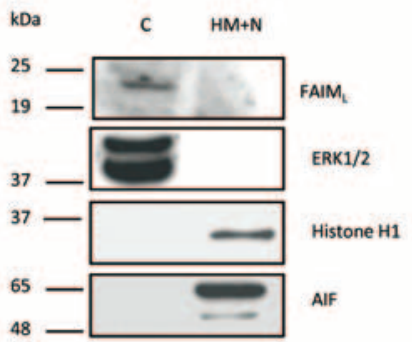

$\mathbf{E}$

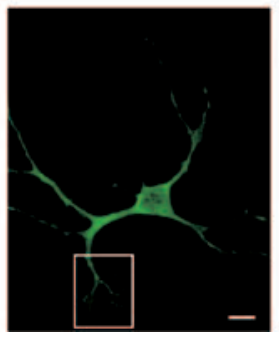

Figure 1. FAIM $\mathrm{L}_{\mathrm{L}}$ is expressed only in the nervous system. $A$, Adult mouse tissue lysates $(20 \mu \mathrm{g})$ were analyzed by SDS-PAGE/ immunoblot using anti-FAIM serum (1:1000) (top panel). As the loading control, the membrane was stained with Naphtol Blue. $B$, Mouse FAIM $\mathrm{L}_{\mathrm{L}}$ RNA tissular content was assessed by semiquantitative RT-PCR with specific primers and compared with L27 housekeeping gene. $C_{\text {, Immunoblot analysis of the FAIM }}$ expression in human and mouse hematopoietic/immune cells as indicated. Cortical neurons, neuroblastoma SH-SY5Y, and transfected PC12 extracts were used as a positive control of the FAIM and total FAIM expression. Twenty micrograms of total protein were resolved by SDS-PAGE and blotted with anti-FAIM (top panel) and FAIM (middle panel). Naphtol blue staining was used as a loading control (bottom panel). D, PC12 cells were lysed in a hypotonic solution, and two crude subcellular fractions were prepared. The equivalent protein content of each fraction was subjected to SDS/PAGE immunoblot analysis using antibodies specific for FAIM ${ }_{L^{\prime}}$ pan-ERK (cytosolic marker), Histone H1 (nuclear marker), and AIF (mitochondria marker). C, Cytosolic fraction; $\mathrm{HM}+\mathrm{N}$, heavy membrane and nuclear fraction. $\boldsymbol{E}$, Subcellular distribution of FAIM $\mathrm{L}_{\mathrm{L}}$. Confocal microscopy $(60 \times)$ of $\mathrm{E} 15$ cortical cells transfected with $F L A G-F A I M_{L}$ and immunofluorescence with anti-FLAG coupled to a secondary anti-mouse conjugated to FITC. Scale bar, $20 \mu \mathrm{m}$. CX, Cortex; CL, cerebellum; HP, hippocampus; HT, heart; SM, skeletal muscle; KD, kidney; SC, spinal cord; LV, liver; LG, lung; NB, Naphtol Blue; C, cytosolic; HM, heavy membranes; $\mathrm{N}$, nuclei.

FAIM $_{\mathrm{S}}$-FLAG constructs. PC12 cells seeded onto $150 \mathrm{~mm}$ tissue culture dishes were transfected using Lipofectamine 2000 with pEYFP (Clontech), pcDNA3-FAIM ${ }_{\mathrm{L}}$-FLAG, pcDNA3-FAIM ${ }_{\mathrm{S}}$-FLAG, HA-FADD, or pcDNA3mFas constructs. When indicated, cells were stimulated with sFasL, $24 \mathrm{~h}$ posttransfection. After $2 \mathrm{~d}$ posttransfection, cells were harvested in lysis buffer CoIP (20 mu Tris/HCl, pH 7.4, 150 mm NaCl, 2 mm EDTA, 10\% Glycerol, $1 \%$ Triton X-100) supplemented with a protease inhibitor mixture (Roche Diagnostics). Lysates were clarified by centrifugation and quantified by the Lowry assay (Bio-Rad). One milligram of total protein was taken and adjusted with the CoIP buffer to achieve a final concentration of $1 \mu \mathrm{g} / \mu \mathrm{l}$. Forty microliters of anti-FLAG M2-agarose-coupled antibody were added to each sample and incubated overnight at $4^{\circ} \mathrm{C}$ in an orbital shaker. Then, beads were washed five times with CoIP buffer and eluted for $30 \mathrm{~min}$ at $4^{\circ} \mathrm{C}$ with 50 $\mu \mathrm{l}$ of TBS containing $150 \mathrm{ng} / \mathrm{ml}$ of 3xFLAG competitor peptide (Sigma). After a short spin, supernatants were carefully taken, Laemli's-loading buffer was added, and SDS-PAGE was performed.

Alternatively, $1 \mathrm{mg}$ of cleared supernatant from PC12 cells was subjected to immunoprecipitation with $2 \mu \mathrm{g}$ of an anti-Fas antibody overnight at $4^{\circ} \mathrm{C}$. Antibodies were recovered with protein- $\mathrm{G}$ and resolved in SDS-PAGE.

\section{Results}

FAIM $_{L}$ is a cytosolic protein predominantly expressed in neurons

With the aim to study FAIM $_{\mathrm{L}}$ expression and distribution, as well as to explore its functional role, we first developed a specific rabbit polyclonal antibody. Because the differential sequence between FAIM $_{S}$ and FAIM $_{\mathrm{L}}$ is 22 aa at the $\mathrm{N}$ terminus of the protein, 16 of these 22 were selected as an antigen. To demonstrate antibody specificity, we analyzed the expression of FAIM $_{\mathrm{L}}$ in lysates from brain (positive control) and liver (used as a negative control). The antibody recognized a single immunoreactive band only in brain lysates with an apparent molecular weight of $\sim 23 \mathrm{kDa}$ (supplemental Fig. $1 \mathrm{~A}$, right panel, available at www.jneurosci.org as supplemental material) that was absent when the membrane was blotted using the preimmune serum (supplemental Fig. 1A, middle panel, available at www.jneurosci.org as supplemental material). We further confirmed that the $\sim 23 \mathrm{kDa}$ band indeed corresponds to FAIM $_{\mathrm{L}}$ by transient transfection of HEK293T cells with increasing amounts of N-terminally FLAG-tagged FAIM $_{\mathrm{L}}$. Duplicate samples were loaded in a gel; one set of samples was blotted with anti-FLAG (supplemental Fig. $1 B$, left panel, available at www.jneurosci.org as supplemental material) and the other with anti-FAIM $_{\mathrm{L}}$ (supplemental Fig. $1 \mathrm{~B}$, right panel, available at www.jneurosci.org as supplemental material). Both antibodies recognize the same band with enhanced intensity corresponding to the increasing amounts of transfected DNA (supplemental Fig. $1 B$, available at www.jneurosci.org as supplemental material). Moreover, we wanted to analyze whether anti-FAIM $\mathrm{L}_{\mathrm{L}}$ antibodies were able to detect the protein in nondenaturing conditions. For this purpose, we synthesized FLAG-tagged FAIM $_{\mathrm{L}}$ using an in vitro reticulocyte-based transcription and translation system (Promega). Reticulocyte suspension was subjected to immunoprecipitation using the antiFAIM $_{\mathrm{L}}$ antibody. Immunoprecipitates were resolved on SDSPAGE gels and blotted with anti-FLAG. Anti-FAIM $\mathrm{L}_{\mathrm{L}}$ antibodies were able to immunoprecipitate FAIM $_{L}$, whereas no signal was detected using a nonrelevant rabbit immune serum (supplemental Fig. 1C, available at www.jneurosci.org as supplemental material).

The anti-FAIM $\mathrm{L}_{\mathrm{L}}$ antiserum was then used to analyze the protein expression profile in different mouse tissues. An immunoreactive band of $\sim 23 \mathrm{kDa}$ was detected in lysates from different brain regions such as cortex, hippocampus, and cerebellum, as well as in spinal cord. No signal was detected in heart, skeletal muscle, kidney, liver, or lung (Fig. 1A). RT-PCR analysis confirms identical specific FAIM $_{\mathrm{L}}$ distribution in the nervous system (Fig. $1 B$ ). Moreover, we analyzed the expression of FAIM $\mathrm{L}_{\mathrm{L}}$ in the hematopoietic/immune system, because of the high relevance of DRs in that system. FAIM $\mathrm{L}_{\mathrm{L}}$ protein expression was not detected in cell lines or in primary lymphocytes but was detected in cerebral cortex lysate used as a positive control. Note that FAIM $_{\mathrm{S}}$ was detected in lymphocytic cell lines (Fig. 1C).

We next examined the subcellular distribution of $\mathrm{FAIM}_{\mathrm{L}}$. For this purpose, PC12 cells were lysed in a hypotonic buffer and 
separated by centrifugation into two subcellular fractions, one containing only cytosolic proteins $(\mathrm{C})$ and the other including heavy membranes and nuclei $(\mathrm{HM}+\mathrm{N})$. FAIM $\mathrm{L}$ was only detected in the cytosolic fraction as determined by immunoblot analysis (Fig. $1 D$, lane C). No signal was detected in the fraction that includes membranes, mitochondria, and nucleus (Fig. $1 D$, lane $\mathrm{HM}+\mathrm{N})$. By reprobing the same blots with antibodies against mitochondrial (AIF), cytosolic (ERK1/2), or nuclear (Histone $\mathrm{H1}$ ) proteins, fractionation procedure (Fig. 1D) was validated. To further analyze the cellular distribution of FAIM $_{L}$ in primary cells, we performed immunofluorescence staining of cortical neurons transiently transfected with FLAG-tagged FAIM $_{\mathrm{L}}$. Confocal microscopy shows a diffuse cytosolic pattern in the soma that excludes the nucleus (Fig. $1 E$ ). Neurite arbors were also positive (Fig. $1 E$, inset). We conclude therefore that $\mathrm{FAIM}_{\mathrm{L}}$ is a cytosolic soluble protein.

To characterize the expression pattern of FAIM $_{L}$ during the development of the CNS, we performed immunohistochemistry using the FAIM $_{\mathrm{L}}$-specific antibody. FAIM $_{\mathrm{L}}$-specific antibodies labeled neurons in most brain regions through development (Fig. 2 ). In contrast, sections incubated with preimmune serum did not exhibit immunostaining (supplemental Fig. $2 \mathrm{~A}-\mathrm{H}$, available at www.jneurosci.org as supplemental material). High levels were detected in the telencephalon (cerebral cortex and hippocampus) and cerebellum. Some brain regions such as the thalamus, septum, caudate-putamen, and globus palidus also showed FAIM $_{\mathrm{L}}$ immunostaining. No relevant expression of FAIM $_{L}$ was found in axonal tracts in any regions of the forebrain or cerebellum (data not shown). In the embryonic cerebral cortex, labeled cells were located in the cortical plate (CP) and in the subplate (SP), corresponding to postmitotic neurons in these layers (Fig. 2A). At P0, cortical plate neurons maintained FAIM $_{\mathrm{L}}$ expression; FAIM $_{\mathrm{L}^{-}}$ positive cells were also found in the cortical layer V (Fig. 2 B). At $\mathrm{P} 5$, the cell bodies and dendrites of layer $\mathrm{V}$ cortical neurons exhibited strong FAIM $\mathrm{L}_{\mathrm{L}}$ immunostaining (Fig. 2C). At postnatal and adult stages, many cortical neurons in layers $\mathrm{V}$ and II-III

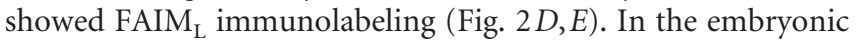
hippocampus, cells in the hippocampal plate expressed FAIM $_{\mathrm{L}}$ (data not shown). At postnatal stages, pyramidal neurons in CA1-3 and some interneurons through all hippocampal layers expressed FAIM $\mathrm{L}_{\mathrm{L}}$. Weak staining was seen in the granule cells of the dentate gyrus (Fig. $2 \mathrm{~F}-\mathrm{H}$ ). The distribution of $\mathrm{FAIM}_{\mathrm{L}^{-}}$ positive cells in the hippocampus was maintained into adulthood (data not shown). The cerebellum also showed an intense FAIM $_{\mathrm{L}}$ immunolabeling. FAIM $_{\mathrm{L}}$ was expressed in migratory Purkinje cells in the embryonic cerebellum (data not shown). At early postnatal stages (P5), the cell bodies of Purkinje neurons expressed high levels of FAIM $\mathrm{L}_{\mathrm{L}}$; Purkinje cell dendrites also showed

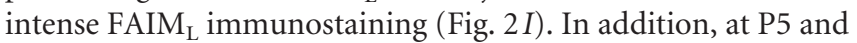
$\mathrm{P} 10$, some interneurons located in the internal granular layer were positive for FAIM $_{\mathrm{L}}$ immunostaining (Fig. $2 \mathrm{~J}, \mathrm{~K}$ ). Purkinje neurons and some cerebellar interneurons maintained the FAIM $_{\mathrm{L}}$ expression at later stages and also through adulthood (Fig. $2 J-L)$.

To confirm that FAIM $_{\mathrm{L}}$ was expressed in neurons, sections from E16, P5, and adult brains were immunoreacted for FAIM and distinct neural markers. Double immunolabeling with FAIM $_{\mathrm{L}}$ antibodies and the pan-neuronal marker NeuN showed an almost complete colocalization of both proteins at all the developmental stages tested (Fig. $2 \mathrm{M}-\mathrm{O}$ ). Similarly, double immunolabeling with FAIM $_{\mathrm{L}}$ antibodies and markers of neuronal subsets (such as calbindin and parvalbumin) (data not shown) further confirmed that $\mathrm{FAIM}_{\mathrm{L}}$ was expressed in neurons (Fig.
$2 P-R)$. Finally, double immunofluorescence studies with cell markers of astroglial cells (GFAP) (supplemental Fig. $2 I-K$, available at www.jneurosci.org as supplemental material), oligodendrocytes (O4) (data not shown), or endothelial cells (CD31) (supplemental Fig. $2 L-N$, available at www.jneurosci.org as supplemental material) did not reveal colocalization with FAIM $_{\mathrm{L}}$ protein. We conclude that $\mathrm{FAIM}_{\mathrm{L}}$ protein is predominantly expressed in developing and adult neurons.

\section{FAIM $_{\mathrm{L}}$ is upregulated during neuronal differentiation}

To obtain quantitative expression data, we performed immunoblots with cortical tissue lysates of mouse brains from different ages. FAIM $\mathrm{L}_{\mathrm{L}}$ levels were low at E12. A moderate increase was detected at E15, and maximum levels were reached at E18. Then, FAIM $_{\mathrm{L}}$ levels were stabilized in the early postnatal stages and in the adult (Fig. 3A). However, levels of FAIM $_{\mathrm{S}}$ were unaltered during development. To determine whether FAIM $\mathrm{L}_{\mathrm{L}}$ is expressed in differentiated cells, levels of the protein were analyzed in cultured cells. The expression of FAIM $\mathrm{L}_{\mathrm{L}}$ was analyzed in cultures of cortical neurons. The FAIM $\mathrm{L}_{\mathrm{L}}$ signal was low at day 0 (a few hours after plating) but increased by threefold with time in culture (Fig. $3 B$ ). Again, levels of $\mathrm{FAIM}_{\mathrm{S}}$ were barely detectable and unchanged during the time course. Next, we analyzed the expression of FAIM in a well characterized differentiation cellular model system. As shown in Figure 3C, NGF induces an increase in FAIM $_{\mathrm{L}}$ mRNA levels up to threefold in PC12 cells when compared with the untreated proliferating cells. Moreover, FAIM $\mathrm{L}_{\mathrm{L}}$ protein amounts increase approximately threefold (after 1, 3, 5, or $7 \mathrm{~d}$ with the neurotrophin) or sixfold (after $9 \mathrm{~d}$ in the presence of the neurotrophin) compared with proliferating control levels (Fig. 3D). However, mRNA and protein levels of FAIM remain unaltered during the different days in the presence of NGF (Fig. $3 C, D)$.

Because FAIM $_{\mathrm{L}}$ was upregulated in response to NGF in PC12 cells, we wanted to determine which signaling pathway was involved in this regulation. Because the MAPK/ERK pathway has been shown to be one of the most relevant for neurotrophininduced neuronal differentiation (Chao, 2003), we analyzed its involvement in $\mathrm{FAIM}_{\mathrm{L}}$ regulation. As shown in Figure $3 E$, NGF induces a significant increase in the $\mathrm{FAIM}_{\mathrm{L}}$ protein content compared with the level observed in proliferating PC12 cells. Treatment of cultures with the microtubule-associated protein kinase kinase (MEK) inhibitor PD98059 blocked the increase of FAIM ${ }_{L}$ after NGF exposure, thus indicating that the MAPK/ERK pathway was primarily responsible for $\mathrm{FAIM}_{\mathrm{L}}$ induction. To further investigate the regulation of $\mathrm{FAIM}_{\mathrm{L}}$ transcription, we cloned the rat FAIM promoter $(2.2 \mathrm{kbp})$ into the luciferase reporter plasmid pGL3-basic. There was basal activation of the FAIM $_{L}$ reporter plasmids in PC12 cells without stimulation, probably because of the fact that PC12 cells express the short form of FAIM. Treatment with NGF further increased luciferase signal. After incubation with MEK1 inhibitor PD98059, the activity of FAIM promoter was reduced to almost nonstimulated luciferase levels, further suggesting that the MAPK/ERK-dependent signaling pathway is the main activator of FAIM $_{\mathrm{L}}$ transcription in PC12 cells (Fig. $3 F$ ). It should be noted that NGF treatment does not induce an increase in the levels of $\mathrm{FAIM}_{\mathrm{S}}$ transcription (data not shown). We could not detect changes in FAIM $_{L}$ expression in NGF-stimulated PC12 cells when the phosphatidyl inositol 3-kinase (PI3K)/Akt or NF- $\kappa \mathrm{B}$ pathways were blocked with LY294002 or the peptide SN50, respectively (data not shown). 

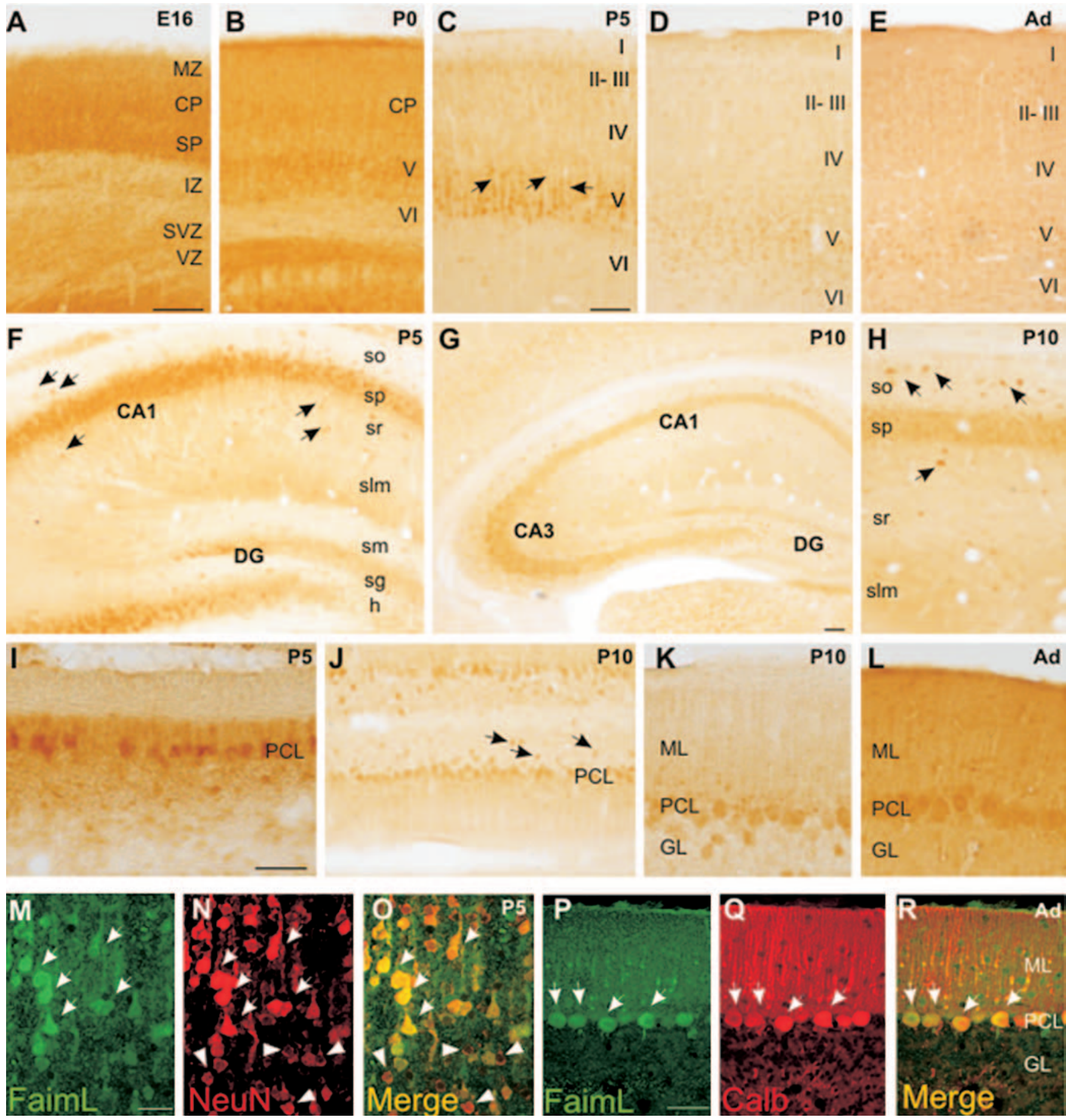

Figure 2. Distribution of FAIM $\mathrm{L}_{-}$-immunoreactive cells during the development of mice brain. $\boldsymbol{A}-\boldsymbol{E}$, In the cortex, many neuronal cell bodies show immunohistochemical labeling. $\boldsymbol{A}$, At E16, neurons in the $\mathrm{CP}$ and $\mathrm{SP}$ contain $\mathrm{FAIM}_{\mathrm{L}} \cdot \boldsymbol{B}$, At $\mathrm{PO}$, some neurons in the incipient layer $\mathrm{V}$ are $\mathrm{FAIM}_{\mathrm{L}}-$ positive cells. In postnatal stages, many neuronal cell bodies and dendrites present $\mathrm{FAIM} \mathrm{L}^{-}$ immunolabeling, mainly in layer $\mathrm{V}\left(\boldsymbol{C}\right.$, arrows). $\boldsymbol{F}-\boldsymbol{H}$, In the hippocampus, many pyramidal neurons and hippocampal interneurons express FAIM $\mathrm{L}_{\mathrm{L}}$, and granular neurons in the dentate gyrus (DG) present weak immunostaining. Some hippocampal interneurons scattered in all hippocampal layers show a strong immunostained signal $(\boldsymbol{F}, \boldsymbol{H}$, arrows). $\boldsymbol{I}-\boldsymbol{L}$, In the cerebellum, the soma and dendrites of Purkinje cells show immunohistochemical staining at all postnatal stages analyzed. Also, some interneurons located in the granular layer $(G L)$ express FAIM $(\boldsymbol{J}$, arrows). $\boldsymbol{M}, \boldsymbol{N}$, Immunofluorescence colocalization (arrows) of $F_{A I M}$ and NeuN proteins in cortical layer $V$ at P5. P- $\boldsymbol{R}$, Immunofluorescence colocalization of FAIM $\mathrm{F}_{\mathrm{L}}$ and calbindin in Purkinje cells (arrows) in the adult cerebellum. MZ, Marginal zone; IZ, intermediate zone; SVZ, subventricular zone; VZ, ventricular zone; CA1-CA3, hippocampal fields; so, stratum oriens; sp, stratum pyramidale; sr, stratum radiatum; slm, stratum lacunosum-moleculare; sm, stratum moleculare; sg, stratum granulosum; h, hilus; ML, molecular layer; PCL, Purkinje cell layer; $G$, granule cell layer. Scale bars: (in $\boldsymbol{A}$ ) $\boldsymbol{A}, \boldsymbol{B}$,

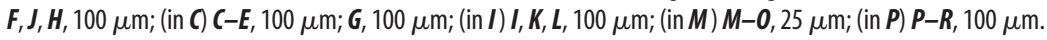

FAIM $_{L}$ and FAIM $S$ play different roles in the nervous system Previous work of our laboratory demonstrated that $\mathrm{FAIM}_{\mathrm{S}}$ overexpression caused an increase in neurite length induced by NGF, both in PC12 cells and in SCG neurons, through the activation of the NF- $\kappa$ B pathway. As such, reduction of endogenous $\mathrm{FAIM}_{\mathrm{S}}$ by RNAi significantly decreased NGF-stimulated neurite outgrowth from PC12 cells and SCG neurons (Sole et al., 2004). In contrast, when forced expression of FAIM $_{L}$ was tested in the same assays, 
A

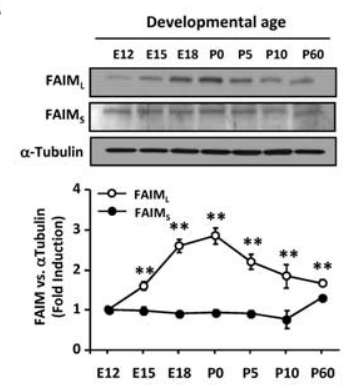

C
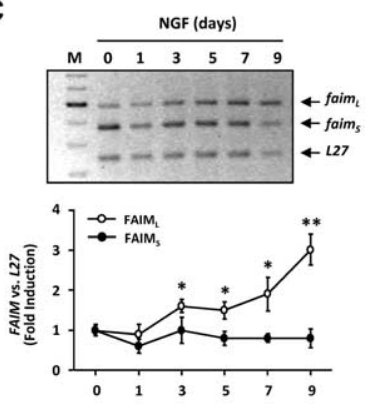

E
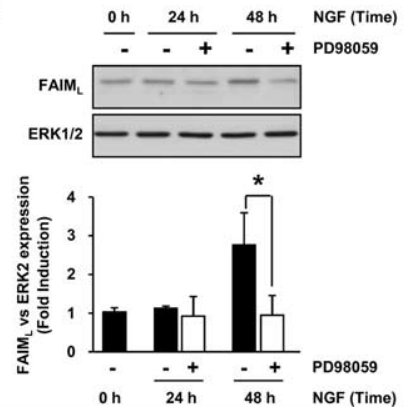

Figure 3. $F A I M_{\perp}$ is upregulated during neuronal differentiation in vitro and in vivo. $\boldsymbol{A}_{\text {, Tem- }}$ poral profile of $F A M_{L}$ expression at the indicated developmental stages. Cortical brain lysates of different embryos were processed, and immunoblots using anti-FAIM ${ }_{L}$ and FAIM $M_{S}$ were performed. $\alpha$-Tubulin was used as a loading control. The bottom panel shows quantification of three independent experiments. $\boldsymbol{B}$, Immunoblot of FAIM $\mathrm{L}_{\mathrm{L}}$ and $\mathrm{FAIM}_{S}$ expression in E12 embryonic cortical neurons at the indicated time points. The bottom panel represents quantification of three different experiments. C, FAIM mRNA expression during NGF-induced PC12 cell differentiation was also assessed using semiquantitative RT-PCR and compared with L27 housekeeping gene. The graph shows a representative experiment out of three. $\boldsymbol{D}_{\boldsymbol{1}}$, Time course of $F A M_{L}$ and FAIM $_{S}$ protein expression in PC12 cells subjected to NGF-induced differentiation. As loading control, membranes were also immunoblotted with an anti-actin antibody. The bottom panel represents quantification of three different experiments. $\boldsymbol{E}$, Immunoblot analysis of $F_{A I M} M_{L}$ levels after NGF exposure of PC12 cells with (+) or without (-) MEK1 inhibitor PD98059 $50 \mu \mathrm{M}$. The histogram shows the quantification of $\mathrm{FAIM}_{\mathrm{L}}$ levels of three independent experiments. $\boldsymbol{F}, \mathrm{PC} 12$ cells were transfected with reporter constructs, pGL3 (empty vector) and pGL3-2.2 kbp, and incubated as indicated (100 ng/ml NGF; $50 \mu \mathrm{M}$ PD98059). Reporter gene activities were measured $48 \mathrm{~h}$ after transfection and after $24 \mathrm{~h}$ of treatment. Phospho-ERK1/2 immunoblot was performed to control the effect of NGF and PD98059 on ERK phosphorylation. NS, Nonstimulated cells. ${ }^{*} p \leq 0.05 ;{ }^{* *} p \leq 0.01$.

no enhanced neurite outgrowth was observed (data not shown). However, the effects of endogenous FAIM $_{\mathrm{L}}$ were not monitored and the possibility that FAIM $_{L}$ might be necessary for neurite formation was not ruled out. To test this hypothesis, we first analyzed the effect of $\mathrm{FAIM}_{\mathrm{L}}$ overexpression in the NF- $\kappa \mathrm{B}$ activity luciferase reporter assay. As shown in Figure $4 A$, no increase in luciferase signal was detected after NGF treatment in FAIM $_{\mathrm{L}^{-}}$ transfected cells $\left(1.88 \times 10^{5} \pm 0.61 \times 10^{5}\right.$ vs control cells, $2.88 \times$ $\left.10^{5} \pm 0.69 \times 10^{5}\right)$. However, a statistically significant increase in NF- $\kappa$ B activity was observed in those transfected with FAIM $_{S}$
A

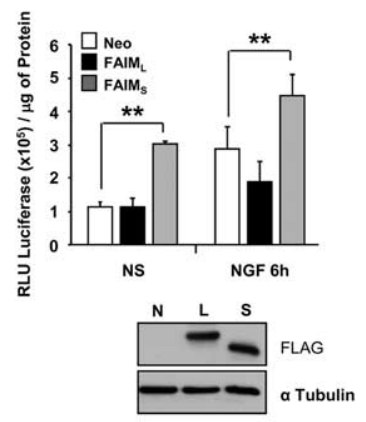

B

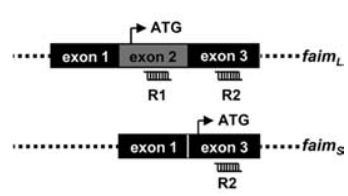

C
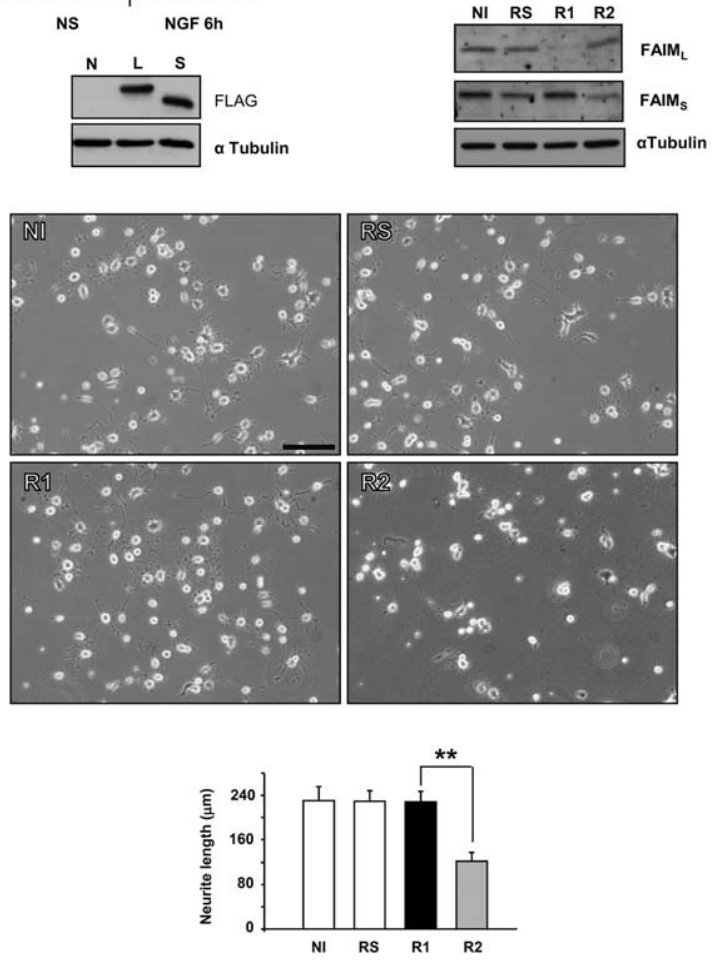

Figure 4. FAIM $M_{S}$ and FAIM have different roles in the nervous system. $\boldsymbol{A}, \mathrm{PC} 12$ cells stably transfected with empty vector $(\mathrm{Neo}, \mathrm{N})$, FLAG-tagged FAIM $(\mathrm{L})$, or FLAG-tagged FAIM $\mathrm{F}_{S}(\mathrm{~S})$ were transfected with 1-2 $\mu \mathrm{g}$ of the reporter vector for NF- $\kappa B$ (HIV-LTR-Luciferase) by electroporation. Cells were stimulated with $100 \mathrm{ng} / \mathrm{ml} \mathrm{NGF}$ for the indicated times or left untreated (NS, nonstimulated), and cell lysates were obtained with $50 \mu$ l of Cell Culture Lysis Reagent (Luciferase Assay System Kit; Promega). Aliquots of supernatant were transferred to a standard 96-well plate for protein concentration determination using Protein Dye agent (Bio-Rad) following manufacturer instructions. Luciferase values were normalized to protein concentration (RLU/ $\mu \mathrm{g}$ of protein). The bottom panels show the control of the transgene expression by Western blot using a FLAG antibody. $\boldsymbol{B}$, Scheme of FAIM $\mathrm{L}_{\mathrm{L}}$ - and FAIM $\mathrm{S}_{\mathrm{S}}$-targeted RNAi design. Positions for the different RNAi are indicated, R1 is sequence specific for FAIM $M_{L}$, and R2 is in the common sequence and specifically silences the $F_{A I M}$ (top panel). $P(12$ cells were infected with $R 1, R 2$, or $R S$ (scrambled) for $72 \mathrm{~h}$, and the effects on endogenous $F A_{I} M_{S / L}$ expression were analyzed by Western blot with anti-FAIM antibodies (bottom panel). $\alpha$-Tubulin was used as a loading control. C, PC12 cells were infected with the lentivirus expressing the RNAi constructs and GFP for $72 \mathrm{~h}$ and then treated with NGF $(100 \mathrm{ng} / \mathrm{ml})$ for one additional day. Representative images

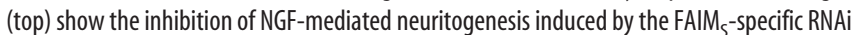
(R2). Both the scrambled (RS) and FAIM ${ }_{\mathrm{L}}$-specific (R1) RNAi sequences resulted in similar NGFinduced neurite outgrowth as in control NI samples. The histogram shows the neurite length measurements of the GFP-positive cells and digitally acquired cultures infected with the indicated RNAi. ${ }^{* *} p \leq 0.01$. Scale bar, $100 \mu \mathrm{m}$.

$\left(4.47 \times 10^{5} \pm 0.62 \times 10^{5}\right.$ vs control cells, $2.88 \times 10^{5} \pm 0.69 \times$ $\left.10^{5}\right)$ even in the absence of NGF $\left(3.00 \times 10^{5} \pm 0.09 \times 10^{5}\right.$ vs control cells, $1.11 \times 10^{5} \pm 0.14 \times 10^{5}$ ) (Fig. $4 A$ ). To further confirm that $\mathrm{FAIM}_{\mathrm{L}}$ has no role in neurite outgrowth, we generated specific short hairpin RNAi (shRNAi) constructs that target different sites of FAIM sequence, which could knock-down specifically FAIM $_{\mathrm{L}}$ or FAIM S RNAi n $^{\circ} 1$ (R1), which targeted exon 2, efficiently downregulated FAIM $_{\mathrm{L}}$ as shown in Figure $4 B$. RNAi n ${ }^{\circ}$ 2 targeted 19 nucleotides after the differential sequence between FAIM $_{\mathrm{L}}$ and FAIM $\mathrm{S}$. This construct minimally affects endogenous 

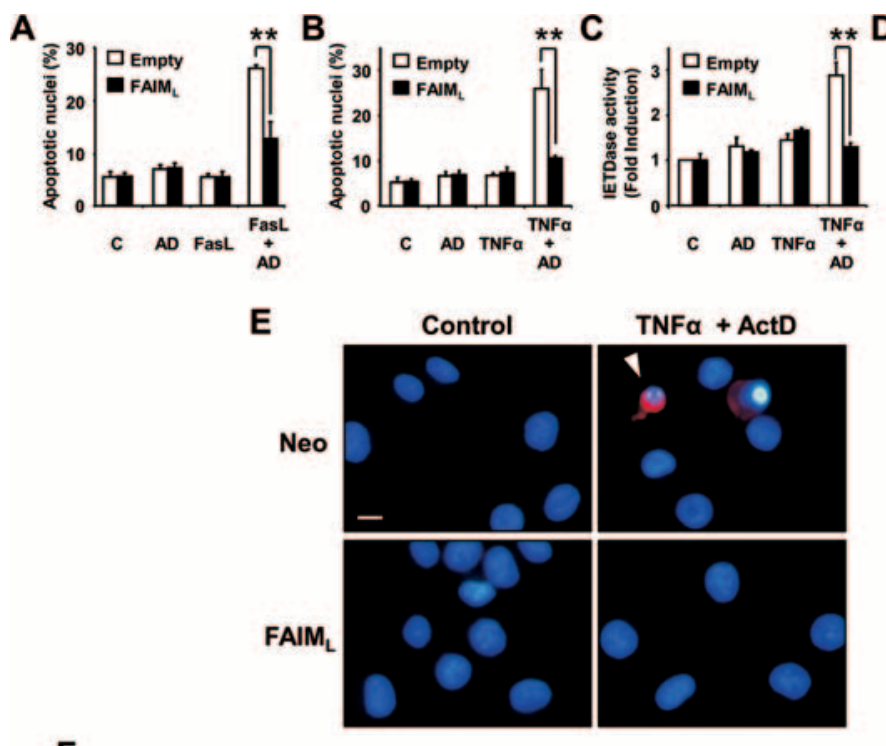

$\mathbf{F}$

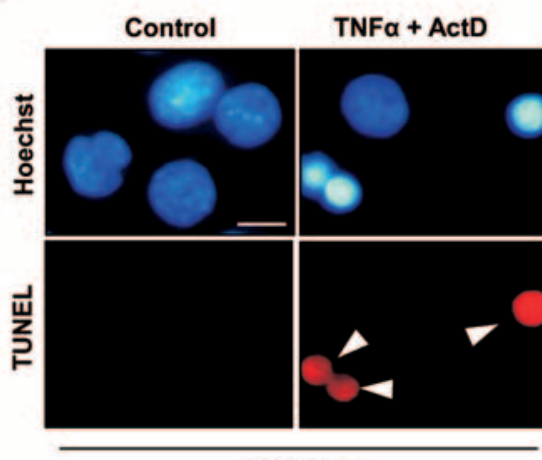

PC12-Neo

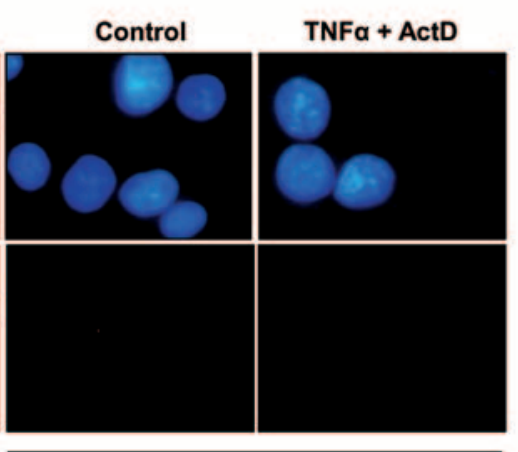

PC12-FAIM
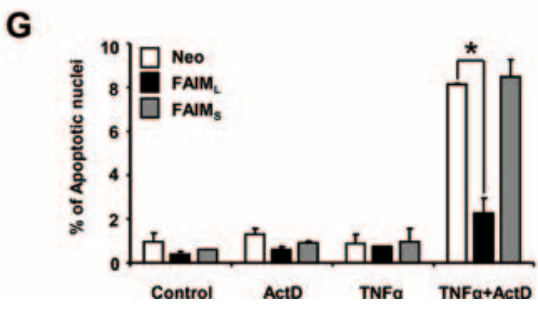

Figure 5. FAIM $\mathrm{L}_{\mathrm{L}}$ overexpression protects $\mathrm{PC12}$ cells from death receptor-induced cell death. Cell death was measured by counting condensed nuclei after Hoechst staining. PC12 cells were infected for $72 \mathrm{~h}$ with lentivirus carrying empty vector (Empty) or FAIM (FAIM $\left._{\mathrm{L}}\right)$ and then were treated or not $(\boldsymbol{C})$ with sFasL $(100 \mathrm{ng} / \mathrm{ml})(\mathrm{FasL})$ for an additional $24 \mathrm{~h}(\boldsymbol{A})$ or with TNF $\alpha(100$ $\mathrm{ng} / \mathrm{ml})(\mathrm{TNF} \alpha)$ or $24 \mathrm{~h}(\boldsymbol{B})$, alone or in combination with ActD (AD) (1 nм). $\boldsymbol{C}$, Caspase activation was measured in the cell lysates after $12 \mathrm{~h}$ of the indicated treatments using z-IETD-afc for caspase 8 or in D, Ac-DEVD-afc for caspase-3 activity. Data were normalized by respect to untreated scrambled infected cells. Data are referred to the respective controls $(n=3)$. $\boldsymbol{E}$, Representative active caspase- 3 immunofluorescence (in red) images were merged with Hoechst 33258 staining (in blue). Note that the typical apoptotic nuclear morphology and active caspase-3 staining only appears in empty-vector (Neo) PC12 cells treated with TNF $\alpha$ / ActD. Arrowheads point to apoptotic cells. $F$, Representative images of TUNEL staining are shown. PC12 cells overexpressing FAIM (PC12-FAIM $\mathrm{L}_{\mathrm{L}}$, but not those carrying an empty construct (PC12-Ne0), were resistant to TNF $\alpha /$ ActD treatment. Arrowheads indicate apoptotic nuclei. Scale bars, $25 \mu \mathrm{m}$. G, Overexpression of FAIM $_{S}$ does not protect against TNF $\alpha / A c t D$-induced apoptosis. Stable PC12 cell lines overexpressing empty vector (Ne0), FAIM $\mathrm{L}^{\prime}$ or $\mathrm{FAIM}_{\mathrm{S}}$ were treated and processed as indicated in $\boldsymbol{B}$. ${ }^{*} p \leq$ $0.05 ;{ }^{* *} p \leq 0.01$.

FAIM $_{\mathrm{L}}$ but efficiently downregulates FAIM $\mathrm{S}$ (Fig. 4B, lane 4). To analyze the effect of RNAi on neurite length, PC12 cells were infected with lentivirus carrying the vectors encoding for the different RNAi. After $72 \mathrm{~h}$, the cells were treated with NGF (100 $\mathrm{ng} / \mathrm{ml}$ ) plus $0.5 \% \mathrm{HS}$ for $1 \mathrm{~d}$, and random pictures were taken in which the neurite length was measured. PC12 cells transduced with scrambled RNAi sequence developed neurite arbors identi-

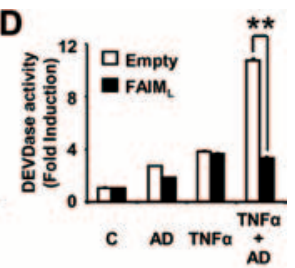

cal to noninfected (NI) cells, indicating that lentiviral infection does not affect NGF-induced neurite outgrowth. Moreover, PC12 cells infected with R1 developed normal neurites indistinguishable from cells noninfected or infected with RS. As expected, PC12 cells infected with R2 significantly decreased their neurite length $(133 \pm 18 \mu \mathrm{m})$ compared with R1infected cells (216 $\pm 24 \mu \mathrm{m})$ (Fig. 4C).

FAIM $_{L}$ prevents death receptor-induced apoptosis in PC12 cell and cortical neurons

Because FAIM $_{\mathrm{S}}$ was initially proposed to be a Fas antagonist (Schneider et al., 1999; Zhong et al., 2001), we investigated whether $\mathrm{FAIM}_{\mathrm{L}}$ could have this role in the nervous system. According to previous data, FasL (Wu et al., 2004) or TNF $\alpha$ (Mielke and Herdegen, 2002) alone did not induce cell death in PC12 cells, whereas in combination with ActD (nM) they induced $25.85 \pm 0.62 \%$ of cell death for FasL and $26.41 \pm 0.28 \%$ for TNF $\alpha$ after $24 \mathrm{~h}$ of treatment, measured by counting the number of apoptotic nuclei after Hoechst staining (Fig. 5A,B). PC12 cells that overexpress FAIM $_{\mathrm{L}}$ are completely resistant to FasL or TNF $\alpha$-induced apoptosis compared with control cells (Fig. $5 A, B)$. Because caspase- 8 has been defined as an apical caspase in both TNF $\alpha$ and Fas-induced cell death, the cleavage of the fluorescent peptide substrate z-IETDafc specific for caspase- 8 was measured (Fig. 5C). Treating PC12 cells with TNF $\alpha$ or ActD alone did not increase the IETDase activity, whereas cotreatment with $\mathrm{TNF} \alpha /$ ActD significantly enhances the activity. When the same experiment was done in PC12 cells overexpressing FAIM $_{\mathrm{L}}$, the IETDase activity was completely blocked in all conditions, including cells treated with TNF $\alpha /$ ActD. Behavior of DEVDase activity (indicative of executor caspases 3/7) was similar to that observed with the IETDase activity (Fig. 5D). In most cases, caspase- 3 activation led to nuclear fragmentation, a well-known hallmark of apoptotic cell death. Figure $5 E$ shows representative micrographs of Hoechst-stained cell nuclei from FAIM $_{\mathrm{L}}$ overexpressing or mock-transfected (PC12-Neo) PC12 cells treated with TNF $\alpha /$ ActD or untreated. After $24 \mathrm{~h}$ of treatment, nuclei from PC12-Neo cells appear rounded and fragmented, displaying a highly compacted chromatin and active Caspase-3 immunostaining (Fig. $5 E$, top right panel). In contrast, PC12-FAIM ${ }_{L}$ cells treated with TNF $\alpha /$ ActD exhibit normal nuclei aspect with homogeneously stained chromatin when compared with untreated cells (Fig. 5E, bottom right and both left panels). In the same way, TNF $\alpha / A c t D$-induced 3'-OH DNA ends 
was only seen in PC12 cells transfected with the empty construct, because cells overexpressing FAIM $_{\mathrm{L}}$ did not exhibit TUNEL positivity after the same treatment (Fig. 5F). In contrast, when the overexpression of FAIM $_{\mathrm{S}}$ was analyzed in the same system, no protection against TNF $\alpha$ / ActD-induced apoptosis was observed (Fig. 5G). Similar results were obtained using primary cultures of cortical cells. As observed in PC12 cells, combined treatment with TNF $\alpha / A c t D$ induced apoptosis in mouse cortical neurons (Fig. 6A). Lentiviral-induced overexpression of FAIM $_{\mathrm{L}}$ blocked death receptor-induced cell death, whereas the overexpression of $\mathrm{FAIM}_{\mathrm{S}}$ did not alter TNF $\alpha /$ ActD-induced cell death. Accordingly, caspase-8 (Fig. $6 B$ ) and caspase-3 (Fig. 6C) activities, as well as cleaved caspase-3-positive neurons (Fig. 6D), were more abundant in empty vector-transduced neurons than in cultures infected with lentiviruses carrying the FAIM $_{\mathrm{L}}$ construct. Moreover, as in PC12 cells, FAIM ${ }_{L}$-transduced cortical neurons did not display TUNEL positivity after TNF $\alpha /$ ActD treatment (Fig. 6E).

FAIM $_{L}$ is an endogenous antagonist of death receptors

To further investigate the relevance of en-

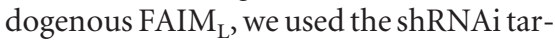
geting system. PC12 cells were transiently infected with FAIM $_{\mathrm{L}}$ RNAi (R1), and apoptotic cell death after death receptor triggering was measured by three different approaches: Hoechst staining, TUNEL assay, and immunofluorescence detection of active caspase-3. FAIM $_{\mathrm{L}}$-knocked-down PC12 cells acquired significant sensitivity to $\mathrm{TNF} \alpha$-induced cell death without the need of treating the cells with ActD (Fig. $7 A-C)$. As expected, PC12 cells infected with the scrambled RNAi sequence (RS) were resistant to TNF $\alpha$. To investigate the mechanism of prevention of $\mathrm{TNF} \alpha$ mediated apoptosis by FAIM $_{\mathrm{L}}$ in PC12 cells, we studied the role of caspases. Caspase- 8 activity increased after TNF $\alpha$ treatment in FAIM $_{\mathrm{L}}$-knocked-down PC12 cells (3.73 \pm 0.41 vs nontreated cells, $1.52 \pm 0.05)$, whereas no activity was detected in scrambled-infected cells (1.23 0.09 vs nontreated cells, $1.0 \pm 0.07$ ) (Fig. $7 D$ ). These data confirm that FAIM $_{\mathrm{L}}$ blocks death receptorinduced apoptosis at the level of or upstream caspase- 8 activation. To confirm RNAi specificity, we reversed the RNAi (R1) effects using a construct expressing a silent mutated FAIM $_{\mathrm{L}}$ (mutFAIM $_{\mathrm{L}}$ ). R1 RNAi was not efficient in reducing the levels of mutFAIM $_{\mathrm{L}}$ (Fig. 7E). As shown in Figure 7F, the apoptotic cell death triggered by TNF $\alpha$ in $\mathrm{FAIM}_{\mathrm{L}}$-knocked-down PC12 cells was almost completely reverted when these cells were infected with viruses carrying the mutFAIM $\mathrm{L}_{\mathrm{L}}$ expression construct (empty vec-

$\mathbf{E}$ 0.01 . Scale bars, $25 \mu \mathrm{m}$
B
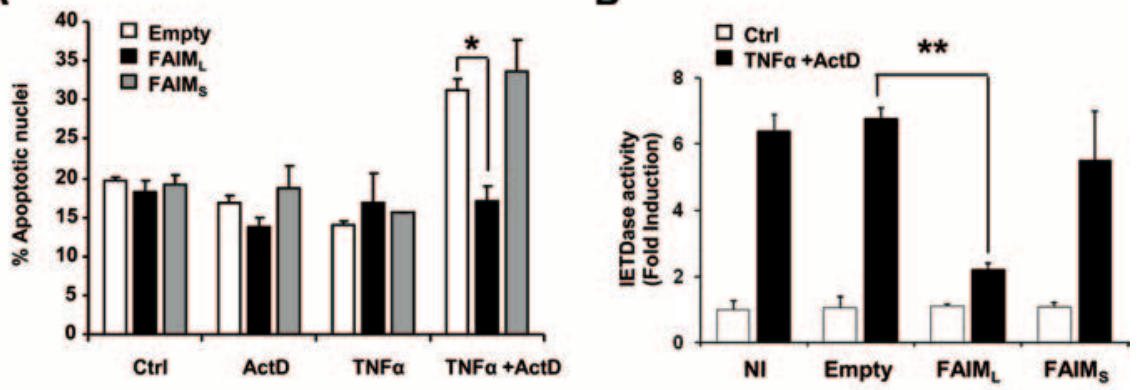

D
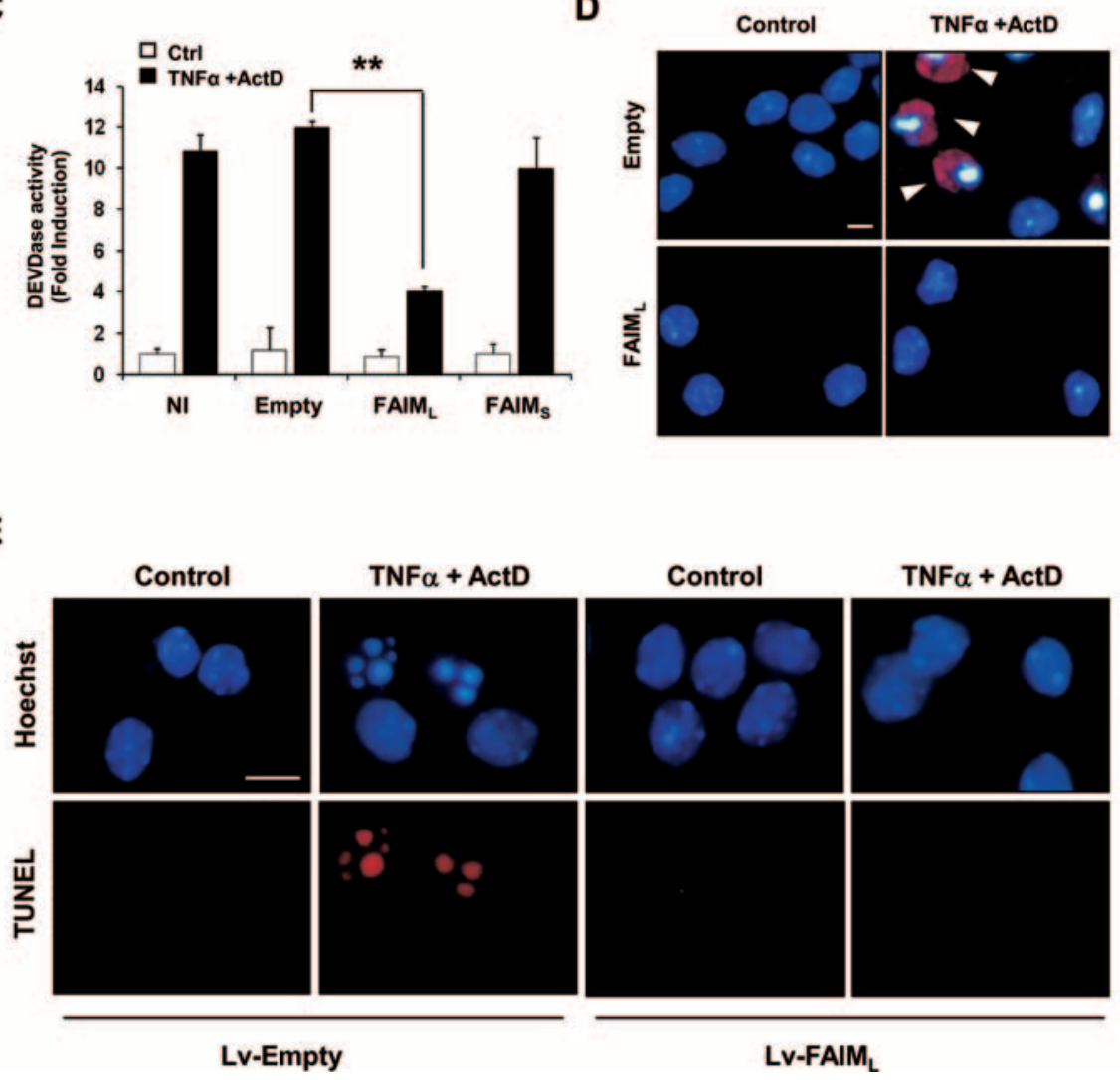

Figure 6. FAIM ${ }_{L}$, but not FAIM $M_{S}$, protects cortical neurons against TNF $\alpha / A c t D$-induced cell death. $A$, E15 mice cortical neurons were infected with lentiviruses carrying empty vector, FAIM $_{S^{\prime}}$ or FAIM for $6 \mathrm{~d}$. At 6 DIV, cells were treated with ActD, TNF $\alpha$, or the combination of both. Twenty-four hours later, cell death was quantified counting apoptotic nuclei after Hoechst staining. $B, C$, Cortical neurons were treated as in $\boldsymbol{A}$, and caspases-8 (B) or $-3(\boldsymbol{C})$ activities were performed. Data were normalized with respect to untreated scrambled infected cells. Data are referred to the respective controls $(n=3)$. $\boldsymbol{D}$, Representative active caspase-3 immunofluorescence (in red) images were merged with Hoechst 33258 staining (in blue). Note that the typical apoptotic nuclear morphology and active caspase-3 staining only appeared in empty vector (Neo) PC12 cells treated with TNF $\alpha / A c t D$ and the lentivirus-based overexpression of $\mathrm{FAIM}_{\mathrm{L}}$ blocked the processing of caspase-3. Arrowheads indicate apoptotic nuclei. $E$, Representative images of TUNEL staining are shown. Cortical neurons infected with viral particles carrying $F A I M_{L}$ construct $\left(L v-F A I M_{L}\right)$, but not those infected with an empty construct (Lv-Empty), were resistant to TNF $\alpha / A c t D$ treatment. Ctrl, Control. ${ }^{*} p \leq 0.05 ;{ }^{* *} p \leq$

tor transfected cells, $12.3 \% \pm 1.22$ vs mutFAIML transfected cells, $5.57 \% \pm 0.37)$.

Motoneurons and cortical neurons use FAIM $_{L}$ as a endogenous antagonist of death receptors

To assess the physiological relevance of endogenous FAIM $_{L}$ in primary neuronal cells, we knocked-down FAIM $_{L}$ in primary neuronal cultures. It has been reported that cortical neurons acquire Fas sensitivity over time in culture (Cheema et al., 1999; 
A

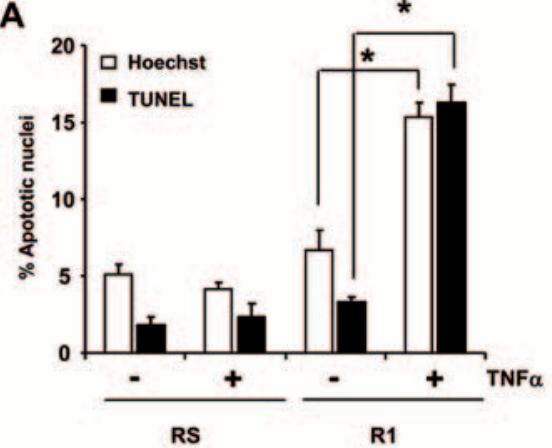

C
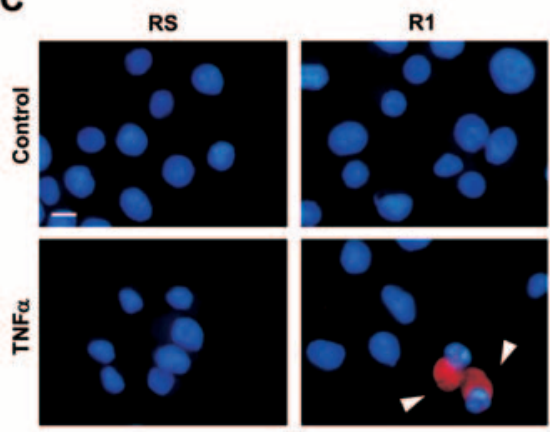

$\mathbf{E}$
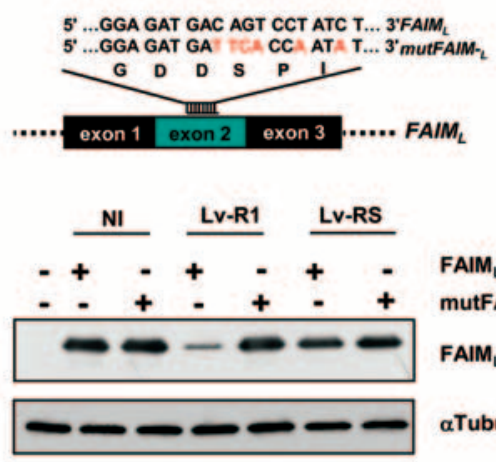

FAIM $_{L}$ mutFAIM FAIM $_{L}$ $\alpha$ Tubulin
B
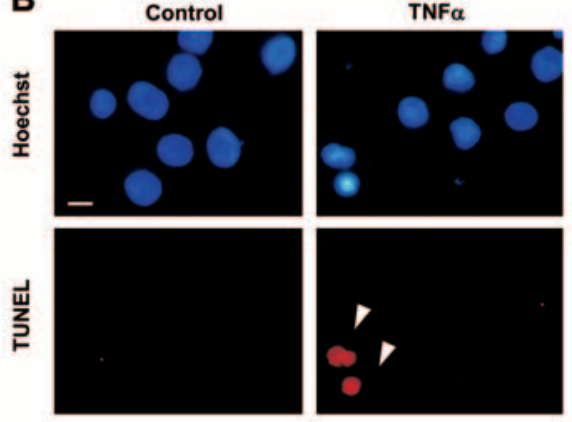

D

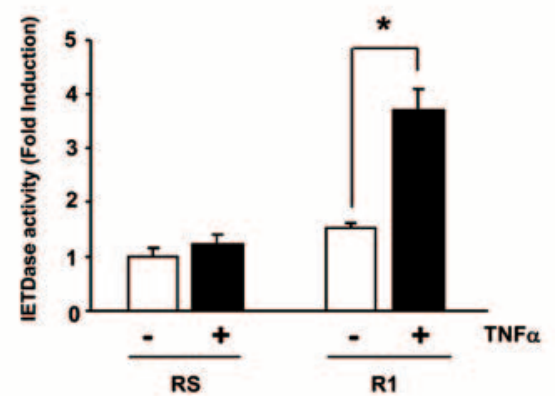

$\mathbf{F}$

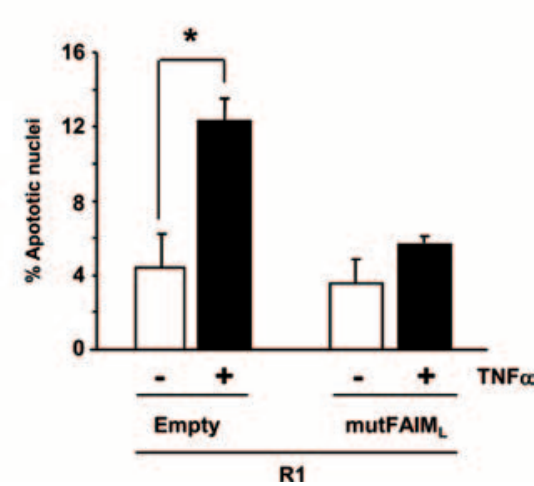

Figure 7. Endogenous FAIM $\mathrm{L}_{\mathrm{L}}$ protects $\mathrm{PC} 12$ cells against $\mathrm{TNF} \alpha$-induced cell death. $A, \mathrm{PC} 12$ cells were infected with $\mathrm{RS}$ or $\mathrm{R} 1$ for $72 \mathrm{~h}$ and then were treated with TNF $\alpha 100 \mathrm{ng} / \mathrm{ml}$ for an additional 24 hours. Cell death was measured by counting apoptotic nuclei after Hoechst staining and by TUNEL assay. $\boldsymbol{B}$, Representative images of the TUNEL assay quantified in $\boldsymbol{A}$. Arrowheads indicate apoptotic nuclei. $\boldsymbol{C}$, Active caspase-3 immunofluorescence. PC12 cells were treated as in $\boldsymbol{A}$, and images show merged pictures of caspase-3 immunofluorescence (red) and Hoechst nuclear staining. Arrowheads indicate apoptotic cells. Scale bars, $25 \mu \mathrm{m}$. $\boldsymbol{D}$, IETDase activity of cell lysates after $12 \mathrm{~h}$ of treatment with TNF $\alpha$. Data are normalized to nontreated scrambled infected cells. $\boldsymbol{E}$,

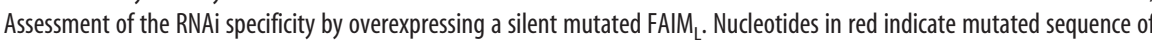
$F_{A I M}$ corresponding to $R 1$ sequence. In the bottom of the figure, Western blot analysis confirmed the specificity of R1 RNAiagainst the nonmutated form of FAIM ${ }_{L}$ with respect to the mutated FAIM $\left(\right.$ mutFAIM ${ }_{L}$ ). Note that RNAi (R1) was not able to reduce the levels of $F A I M_{\perp}$ in the cells expressing mutFAIM ${ }_{\perp}, F, P C 12$ cells were infected with $R 1$ and empty vector or mutFAIM $M_{\perp}$. After $72 \mathrm{~h}$, cells were treated with $\operatorname{TNF} \alpha$, and cell death was measured $24 \mathrm{~h}$ later by Hoechst staining and scoring apoptotic nuclei. ${ }^{*} p \leq 0.05$.

Zuliani et al., 2006), whereas they retain resistance to $\mathrm{TNF} \alpha$ (Eves et al., 2001; Rickle et al., 2006). R1-infected cortical neurons acquire TNF $\alpha$ and enhanced Fas sensitivity as assessed by analysis of the nuclear chromatin fragmentation after Hoechst staining [24.84 $\pm 1.09 \%$ for TNF $\alpha$ and $23.74 \pm 1.09 \%$ for Jo2 in R1infected cells vs $7.68 \pm 0.57 \%$ (TNF $\alpha$-treated) and $16.45 \pm 1.89$ (Jo2-treated) in RS-infected cells] (Fig. 8A,B), TUNEL assay $[33.85 \pm 2.70 \%$ for TNF $\alpha$ and $25.29 \pm 1.60 \%$ for Jo2 in R1infected cells vs $11.04 \pm 1.77 \%$ (TNF $\alpha$-treated) and $13.29 \pm 0.62$ (Jo2-treated) in RS-infected cells] (Fig. 8C,D) and trypan blue exclusion assay (data not shown). To confirm these results in a well-characterized cellular model where DRs have been shown to have a relevant function (Raoul et al., 2002; Demjen et al., 2004; Raoul et al., 2006; Wen et al., 2006), we performed a series of comparable experiments using spinal cord motoneurons. Motoneurons infected with the R1 sequence show an increase of apoptotic cell death compared with the scrambled infected cells after either Fas or TNFR1 engagement $(23.12 \pm 4.33 \%$ for control cells; $39.76 \pm 4.40 \%$ for R1/TNF-treated cells, and $47.39 \pm 4.60 \%$ for R1/Fastreated cells) (Fig. 8E,F). Altogether, these results confirm the physiological implication of FAIM $_{\mathrm{L}}$ in neuronal resistance against death receptor-triggered apoptosis, placing it as a new intracellular player in the regulation of cellular responses during nervous system development.

FAIM $_{L}$, but not FAIM $_{S}$, interacts with Fas, and its binding can be displaced by FADD

Finally, because DR-triggered caspase- 8 activation is abrogated in cells overexpressing FAIM $_{\mathrm{L}}$, we wanted to determine whether FAIM $_{L}$ acts upstream of this caspase. To this end, we checked whether FAIM $_{L}$ could interact with DRs. As shown in Figure 9A, Fas constitutively associates with an exogenously transfected FLAGtagged FAIM $_{L}$ without stimulation with FasL. Moreover, the binding of FAIM $\mathrm{L}_{\mathrm{L}}$ to Fas can be reverted when cells are stimulated with FasL (Fig. 9B). In contrast, FAIM failed to coimmunoprecipitate with Fas, irrespectively of the presence of FasL in the culture media (Fig. 9A,B). The interaction between endogenous FAIM $_{L}$ and Fas was confirmed in PC12 cells. The specific immunoprecipitation of Fas from untreated PC12 cell lysates shows that endogenous FAIM $_{L}$ interacts with this DR. As expected, control iso-specific immunoglobulin (IgG) failed to immunoprecipitate Fas and, in consequence, FAIM $_{\mathrm{L}}$ (Fig. 9C). In the same way, FAIM $_{L}$ was also able to interact with endogenous Fas in PC12 cells overexpressing FAIM $_{L}$ (Fig. 9C). To assess whether the adaptor protein FADD could revert the interaction between FAIM $_{\mathrm{L}}$ and Fas, we performed combined transfections of FLAG-FAIM $\mathrm{L}_{\mathrm{L}}$ with HA-FADD, Fas, or both. As shown in Figure 9D, the overexpression of FADD fully prevented the interaction between $\mathrm{FAIM}_{\mathrm{L}}$ and Fas, although Fas was expressed at high levels (Fig. 9D). These data, together with the anti-apoptotic role of $\mathrm{FAIM}_{\mathrm{L}}$, suggest that this protein must block DR-triggered apoptotic cell death at the level of the DR complex.

\section{Discussion}

Signaling pathways controlling neuronal death and survival are crucial for the normal development and function of the nervous 
system. In contrast to most cell types, neurons survive for the lifetime of the organism and therefore need to possess powerful intracellular mechanisms to antagonize cell death stimuli. FAIM $\mathrm{L}_{\mathrm{L}}$ was described as a splice variant of FAIM (Zhong et al., 2001) and has remained without any defined function. Here, we describe that FAIM $_{\mathrm{L}}$ is an antagonist of death receptortriggered apoptosis in the nervous system. FAIM $_{\mathrm{L}}$ overexpression is able to prevent the death induced by treating cells with TNF $\alpha$ or FasL plus ActD. Moreover, reducing the endogenous levels of FAIM $_{L}$ with RNA interference constructs sensitizes to DR-induced apoptosis in otherwise resistant primary neurons.

We reported previously that FAIM $_{S}$ increases neurite outgrowth induced by neurotrophic factors in cultured neurons through the increased activation of the NF- $\kappa$ B pathway (Sole et al., 2004). Here, we report that reduction of FAIM $_{\mathrm{L}}$ does not modify the NGF-induced neurite outgrowth in PC12 cells (Fig. 4C). Accordingly, FAIM $_{\mathrm{L}}$ does not modulate the NGF activation of the NF- $\kappa \mathrm{B}$ pathway (Fig. $4 A)$. Additional differences between FAIM splicing isoforms include that FAIM $_{\mathrm{S}}$ overexpression is unable to prevent the death induced by DR triggering (Fig. 5G). The final and most relevant difference between both isoforms is that FAIM $_{\mathrm{L}}$ is able to bind nonstimulated Fas, whereas FAIM $_{S}$ does not (Fig. 9). Together, these results demonstrate that these molecules have vastly different functions.

Fas ligand (Bechmann et al., 1999) and its cognate receptor Fas (Park et al., 1998; Cheema et al., 1999) are highly expressed in the nervous system, especially during development. However, natural mouse mutations for Fas $(l p r)$ or FasL ( $g l d)$ do not present major defects in the number of neurons in any of the populations analyzed (Kovac et al., 2002). In mature adult neurons, the Fas-FasL system seems to play an important role during certain pathological situations. Thus, mice injected with functional antibodies against FasL, as well as $l p r$ and gld mice show a significant resistance to stroke in vivo (Martin-Villalba et al., 1999, 2001; Graham et al., 2004) and to apoptosis after traumatic spinal cord injury (Yoshino et al., 2004; Casha et al., 2005). Neutralizing antibodies to FasL promote regeneration and functional recovery after spinal cord injury (Demjen et al., 2004; Ackery et al., 2006). However, neuronal populations, with the exception of immature motoneurons (Raoul et al., 1999, 2002), show either very limited apoptosis or complete resistance to Fas-induced cell death in vitro (Gerhardt et al., 2001; Putcha et al., 2002), even if they express Fas receptor. These data presume the existence of natural antagonists
B

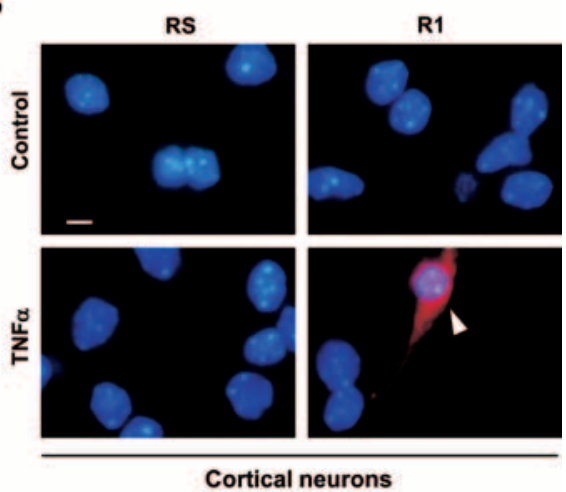

D

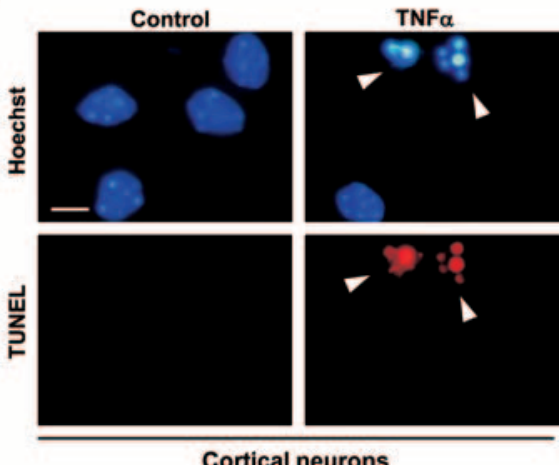

Cortical neurons

$\mathbf{F}$ RS
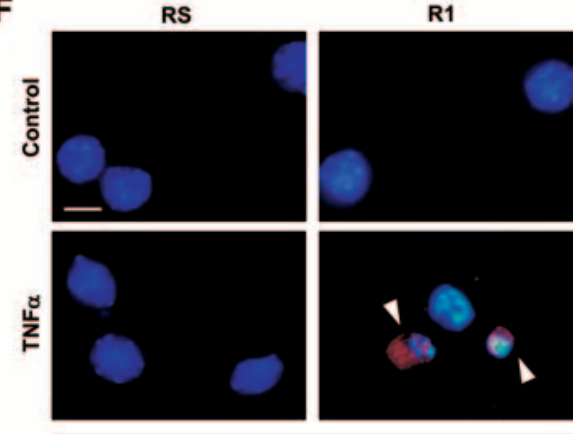

Motoneurons

Figure 8. Endogenous FAIM $M_{L}$, but not FAIM , is responsible for the resistance of primary neurons to DR activation. $A, E 15$ cortical neurons were infected with R1, R2, or RS for $72 \mathrm{~h}$ before Fas-J02 $(5 \mu \mathrm{g} / \mathrm{ml})$ and TNF $\alpha(100 \mathrm{ng} / \mathrm{ml})$ treatment. Twenty-four hours later, apoptotic cell death was determined by scoring the percentage of apoptotic cells after Hoechst staining. $\boldsymbol{B}$, E15 cortical neurons were treated as in $\boldsymbol{A}$. Twenty-four hours later, active caspase- 3 was detected by immun ofluorescence. Images show active caspase-3 immunofluorescence (red) merged with Hoechst staining. C, E15 cortical neurons were infected and treated as indicated in $\boldsymbol{A}$. Then, apoptosis was assessed by the TUNEL assay. $\boldsymbol{D}$, Representative images of $\boldsymbol{C} . \boldsymbol{E}$, E12.5 mice motoneurons were infected with lentiviruses for $5 \mathrm{~d}$. Then, cells were treated with Fas-J02 $(1 \mu \mathrm{g} / \mathrm{ml})$ or TNF $\alpha(100 \mathrm{ng} / \mathrm{ml})$ for an additional $24 \mathrm{~h}$. Percentage of cell death was measured by Hoechst staining of nuclei and counting apoptotic profiles. $F$, Immunofluorescence of active caspase-3. Images are the result of merging Hoechst staining with active caspase-3 immunofluorescence. Ctrl, Control. ${ }^{*} p \leq 0.05$; ${ }^{* *} p \leq 0.01$. Scale bars, $25 \mu \mathrm{m}$. Arrowheads indicate apoptotic cells $(\boldsymbol{B}, \boldsymbol{F})$ and nuclei $(\boldsymbol{D})$.

of the DRs, and several have been shown to be expressed in the nervous system. c-FLIP is a widely expressed molecule that mediates resistance to DR-induced death in a wide range of cellular models, including lymphocytes and endothelial cells (Irmler et al., 1997; Thome et al., 1997; Yeh et al., 2000). In addition, Raoul et al. (1999) have reported that c-FLIP could be responsible for the resistance to DR-triggered cell death in embryonic motoneurons. Although the anti-apoptotic role of FLIP is well established, its implication as a DR antagonist in neurons is not conclusive. In 


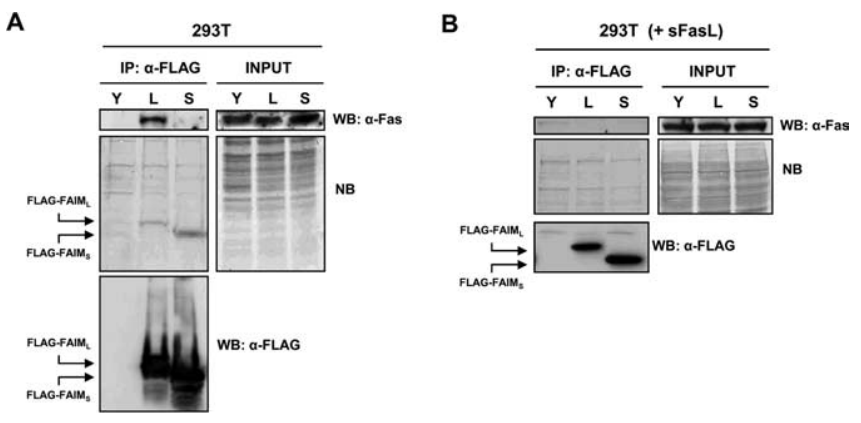

C
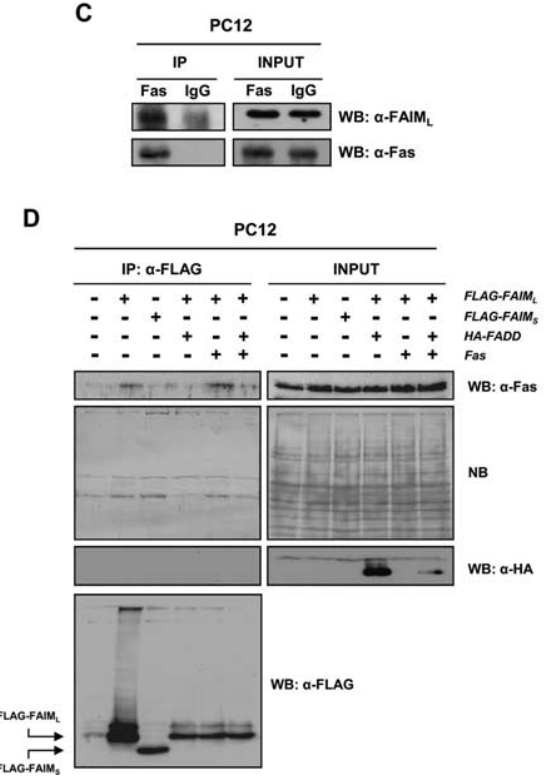

Figure 9. FAIM $M_{L}$ associates with Fas. A, HEK293T cells were transiently transfected with pEYFP (Y), pcDNA3-FAIM - -FLAG (L), or pcDNA3-FAIM - FLAG (S). After $24 \mathrm{~h}$, lysates were performed and subjected to immunoprecipitation using FLAG-specific mAb M2-coupled agarose beads (Sigma). The immunoprecipitates (eluted fractions) were resolved by SDS-PAGE, and proteins were transferred onto PVDF membranes and immunoblotted with anti-Fas (top panels) or anti-FLAG (M2) (bottom panel) antibodies. All membranes were also stained with Naphtol Blue to confirm equal loading (middle panels). B, HEK293T cells transfected as in $\boldsymbol{A}$ were left untreated or treated with soluble FasL (sFasL). Western blots were performed as stated for $\boldsymbol{A}$. $\boldsymbol{C}$ One milligram of PC12 cell lysate was immunoprecipitated (IP) with anti-Fas antibody (Fas) followed by Western blot with either FAIM (top panels) or Fas (bottom panels) antibodies. A nonrelevant iso-specific antibody ( $\mathrm{lgG}$ ) was used as a negative control. $\boldsymbol{D}, \mathrm{PC} 12$ cells were transiently transfected with different constructions carrying FLAG-FAIM, FLAG-FAIM $\mathrm{S}_{\mathrm{L}}$ HAFADD, and/or pcDNA3-mFas (Fas). After $48 \mathrm{~h}$, immunoprecipitation and Western blot analysis were performed as in $\boldsymbol{A}$. Blotting the membranes with anti-HA confirmed the PC12 cells transfection with the HA-FADD construct. When FADD was overexpressed, there was no longer any interaction between FAIM $_{L}$ and Fas.

fact, it has been demonstrated that FLIP is not responsible in mediating Fas-resistance in vitro cultured embryonic neurons (Beier et al., 2005). Because it has been demonstrated that both death ligands (DLs) and DRs are expressed during the neuronal development (Cheema et al., 1999) and in the adult brain (Bette et al., 2003; Choi and Benveniste, 2004), other intracellular regulators distinct of FLIP that are able to antagonize DR-mediated cell death must exist.

Another molecule described as an antagonist of death receptors in the nervous system is LFG (also known as neuronal membrane protein 35, NMP35) (Somia et al., 1999; Schweitzer et al., 2002; Beier et al., 2005; Fernández et al., 2007). LFG is predominantly expressed in the nervous system (Schweitzer et al., 2002) and has been shown to be the molecule responsible for Fas death resistance in cerebellar granule neurons (Beier et al., 2005; Fernández et al., 2007). However, a relevant difference with $\mathrm{FAIM}_{\mathrm{L}}$ is that LFG is not able to protect from death induced by TNF $\alpha$ (Somia et al., 1999). Whereas expression of FAIM $\mathrm{L}_{\mathrm{L}}$ is maximal during embryonic or early postnatal stages, the expression of LFG continuously increases during development and reaches maximal levels in the adult (Schweitzer et al., 2002). This suggests that LFG could be more significant in neuronal injuries that occur in the adult.

Neurotrophins exert their anti-apoptotic function by the activation of diverse intracellular pathways. One of the main mechanisms involved in the cellular resistance to DR-triggered apoptosis is the transcriptional regulation of DR modulators (Tran et al., 2004). In this way, the activation of the MAPK/ERK pathway suppresses Fas-mediated apoptosis in diverse cellular systems (Tran et al., 2001). We observed that NGF activates FAIM $_{L}$ promoter through the activation of the MAPK/ERK pathway in PC12 cells. In contrast, LFG is regulated by PI3K-Akt/protein kinase B (Beier et al., 2005), and c-FLIP is mainly controlled by

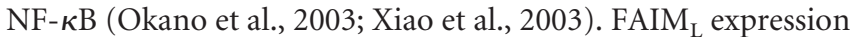
was unaffected by the inhibition of these pathways. Neither the PI3K inhibitor LY294002 nor the p65 SN50 inhibitor for NF- $\kappa \mathrm{B}$ modified NGF-regulation of the FAIM $_{\mathrm{L}}$ promoter in PC12 cells (data not shown).

Here, we show that the overexpression of FAIM $_{\mathrm{L}}$ abolishes DR-induced caspase- 8 activation and, therefore, apoptotic cell death in PC12 cells and in embryonic primary neurons. Moreover, the knock-down of endogenous $\mathrm{FAIM}_{\mathrm{L}}$ sensitizes embryonic neurons to apoptosis mediated by DR engagement, in a caspase-8-dependent manner. Altogether, these data suggest that the inhibition of DR-induced caspase- 8 activation depends on the levels of anti-apoptotic molecules like FAIM $_{L}$. In Figure 9, we show that in basal conditions, FAIM $_{\mathrm{L}}$, but not FAIM , is able to interact with Fas. This interaction is no longer observed when cells were treated with FasL, therefore suggesting that activation of the receptor displaces the binding of FAIM $_{L}$. Furthermore, we show that FADD competes with FAIM $_{\mathrm{L}}$ for the binding to Fas. This behavior is similar to what was reported for the silencer of death domains (SODD) (Jiang et al., 1999; Tschopp et al., 1999). SODD is a widely expressed protein that is normally associated with the death domain of TNF-R1 or DR3. When the receptor is stimulated, SODD is released, permitting the recruitment of TRADD (TNF receptor-associated death domain) and TRAF2 (TNF receptor-associated factor 2 ) to the active receptor (Jiang et al., 1999). However, the mice without SODD develop normally and do not show any major defects in death receptor signaling, thus suggesting the existence of other redundant gene (Endres et al., 2003). Although we have not completely characterized the mechanisms of FAIM $\mathrm{L}_{\mathrm{L}}$ antagonism and FAIM $_{\mathrm{L}}$ and SODD are not structurally related, our results favor the view that $\mathrm{FAIM}_{\mathrm{L}}$ could be a SODD-like molecule specifically expressed in the nervous system.

We reported that $\mathrm{FAIM}_{\mathrm{L}}$ is upregulated during the embryonic stages when DLs and DRs like Fas/FasL or TNF-RI and RII/TNF $\alpha$ are expressed in neuronal regions that do not show increased apoptosis (Nadeau and Rivest, 1999; Kovac et al., 2002). In this regard, we observe that $\mathrm{FAIM}_{\mathrm{L}}$ upregulation strongly correlates with the neuronal expression of DRs such as TNF-RI, TNF-RII (Bette et al., 2003), and Fas (Zuliani et al., 2006). For instance, Fas is expressed at E15 and its levels are maintained until early postnatal stages. FAIM $\mathrm{L}_{\mathrm{L}}$ and Fas share similar expression patterns that are particularly strong in the hippocampus, cerebellum, and cortical layers II-III and V of the neocortex, specially in pyramidal 
neurons (Zuliani et al., 2006). We also demonstrate that $\mathrm{FAIM}_{\mathrm{L}}$ is a powerful inhibitor of apoptosis mediated by the activation of DRs such as Fas and TNF-Rs. Therefore, we can argue that FAIM $_{\mathrm{L}}$ could be a key modulator of DR-triggered apoptosis during development of different embryonic neuronal populations of the CNS.

Other functions have been proposed for the expression of the Fas-FasL system during development of the nervous system. Thus, for example, Fas engagement has been shown to induce neurite outgrowth in dorsal root ganglion neurons in vitro and promote the functional recovery in vivo of transacted sciatic nerves (Desbarats et al., 2003). Similarly, the Fas-FasL system has been involved in controlling neuronal branching, and, importantly, both $l p r$ and gld mice show reduced dendritic branching during development (Zuliani et al., 2006). These effects are caspase independent. Because $\mathrm{FAIM}_{\mathrm{L}}$ does not regulate classical survival/differentiation pathways such as PI- $3 \mathrm{~K}, \mathrm{NF}-\kappa \mathrm{B}$, or ERK/ MAPK activated by neurotrophins, it is tempting to speculate that the anti-apoptotic function of FAIM $_{\mathrm{L}}$ may act as a critical switch on the biological consequences derived from DR triggering, overriding the apoptotic death cascades.

In summary, we provide, for the first time, the involvement of the splice variant of the anti-apoptotic protein FAIM in the regulation of DR-triggered neuronal death. FAIM $_{\mathrm{L}}$ overexpression blocks DR-induced cell death, and the endogenous protein is required for neuronal resistance against DR-mediated apoptosis. This mode of action strictly depends on the inhibition of apical caspases, like caspase-8, at the level of the receptor complex.

\section{References}

Ackery A, Robins S, Fehlings MG (2006) Inhibition of Fas-mediated apoptosis through administration of soluble Fas receptor improves functional outcome and reduces posttraumatic axonal degeneration after acute spinal cord injury. J Neurotrauma 23:604-616.

Arce V, Pollock RA, Philippe JM, Pennica D, Henderson CE, deLapeyriere O (1998) Synergistic effects of Schwann- and muscle-derived factors on motoneuron survival involve GDNF and cardiotrophin-1 (CT-1). J Neurosci 18:1440-1448.

Bayascas JR, Yuste VJ, Sole C, Sanchez-Lopez I, Segura MF, Perera R, Comella JX (2004) Characterization of splice variants of human caspaseactivated DNase with CIDE-N structure and function. FEBS Lett 566:234-240.

Bechmann I, Mor G, Nilsen J, Eliza M, Nitsch R, Naftolin F (1999) FasL (CD95L, Apo1L) is expressed in the normal rat and human brain: evidence for the existence of an immunological brain barrier. Glia 27:62-74.

Beier CP, Wischhusen J, Gleichmann M, Gerhardt E, Pekanovic A, Krueger A, Taylor V, Suter U, Krammer PH, Endres M, Weller M, Schulz JB (2005) FasL (CD95L/APO-1L) resistance of neurons mediated by phosphatidylinositol 3-kinase-Akt/protein kinase B-dependent expression of lifeguard/neuronal membrane protein 35. J Neurosci 25:6765-6774.

Bette M, Kaut O, Schafer MK, Weihe E (2003) Constitutive expression of p55TNFR mRNA and mitogen-specific up-regulation of TNF alpha and p75TNFR mRNA in mouse brain. J Comp Neurol 465:417-430.

Boldin MP, Varfolomeev EE, Pancer Z, Mett IL, Camonis JH, Wallach D (1995) A novel protein that interacts with the death domain of Fas/APO1 contains a sequence motif related to the death domain. J Biol Chem 270:7795-7798.

Casha S, Yu WR, Fehlings MG (2005) Fas deficiency reduces apoptosis, spares axons and improves function after spinal cord injury. Exp Neurol 196:390-400.

Chao MV (2003) Neurotrophins and their receptors: a convergence point for many signalling pathways. Nat Rev Neurosci 4:299-309.

Cheema ZF, Wade SB, Sata M, Walsh K, Sohrabji F, Miranda RC (1999) Fas/Apo [apoptosis]-1 and associated proteins in the differentiating cerebral cortex: induction of caspase-dependent cell death and activation of NF- $\kappa$ B. J Neurosci 19:1754-1770.

Choi C, Benveniste EN (2004) Fas ligand/Fas system in the brain: regulator of immune and apoptotic responses. Brain Res Brain Res Rev 44:65-81.
Comella JX, Sanz-Rodriguez C, Aldea M, Esquerda JE (1994) Skeletal muscle-derived trophic factors prevent motoneurons from entering an active cell death program in vitro. J Neurosci 14:2674-2686.

Cullen BR (1987) Use of eukaryotic expression technology in the functional analysis of cloned genes. Methods Enzymol 152:684-704.

Demjen D, Klussmann S, Kleber S, Zuliani C, Stieltjes B, Metzger C, Hirt UA, Walczak H, Falk W, Essig M, Edler L, Krammer PH, Martin-Villalba A (2004) Neutralization of CD95 ligand promotes regeneration and functional recovery after spinal cord injury. Nat Med 10:389-395.

Desagher S, Martinou JC (2000) Mitochondria as the central control point of apoptosis. Trends Cell Biol 10:369-377.

Desbarats J, Birge RB, Mimouni-Rongy M, Weinstein DE, Palerme JS, Newell MK (2003) Fas engagement induces neurite growth through ERK activation and p35 upregulation. Nat Cell Biol 5:118-125.

Endres R, Hacker G, Brosch I, Pfeffer K (2003) Apparently normal tumor necrosis factor 1 signaling in the absence of the silencer of death domains. Mol Cell Biol 23:6609-6617.

Eves EM, Skoczylas C, Yoshida K, Alnemri ES, Rosner MR (2001) FGF induces a switch in death receptor pathways in neuronal cells. J Neurosci 21:4996-5006.

Fernández M, Segura MF, Sole C, Colino A, Comella JX, Ceña V (2007) Lifeguard/neuronal membrane protein 35 regulates Fas ligand-mediated apoptosis in neurons via microdomain recruitment. J Neurochem 103:190-203

Gerhardt E, Kugler S, Leist M, Beier C, Berliocchi L, Volbracht C, Weller M, Bahr M, Nicotera P, Schulz JB (2001) Cascade of caspase activation in potassium-deprived cerebellar granule neurons: targets for treatment with peptide and protein inhibitors of apoptosis. Mol Cell Neurosci 17:717-731.

Graham EM, Sheldon RA, Flock DL, Ferriero DM, Martin LJ, O'Riordan DP, Northington FJ (2004) Neonatal mice lacking functional Fas death receptors are resistant to hypoxic-ischemic brain injury. Neurobiol Dis 17:89-98

Harlow DL (1988) Antibodies: a laboratory manual. Cold Spring Harbor, New York: Cold Spring Harbor Laboratory.

Iglesias M, Segura MF, Comella JX, Olmos G (2003) Mu-opioid receptor activation prevents apoptosis following serum withdrawal in differentiated SH-SY5Y cells and cortical neurons via phosphatidylinositol 3-kinase. Neuropharmacology 44:482-492.

Irmler M, Thome M, Hahne M, Schneider P, Hofmann K, Steiner V, Bodmer JL, Schroter M, Burns K, Mattmann C, Rimoldi D, French LE, Tschopp J (1997) Inhibition of death receptor signals by cellular FLIP. Nature 388:190-195.

Jiang Y, Woronicz JD, Goeddel DV (1999) Prevention of constitutive TNF receptor 1 signaling by silencer of death domains. Science 283:543-546.

Kovac AD, Grammig J, Mahlo J, Steiner B, Roth K, Nitsch R, Bechmann I (2002) Comparison of neuronal density and subfield sizes in the hippocampus of CD95L-deficient (gld), CD95-deficient (lpr) and nondeficient mice. Eur J Neurosci 16:159-163.

Liston P, Young SS, Mackenzie AE, Korneluk RG (1997) Life and death decisions: the role of the IAPs in modulating programmed cell death. Apoptosis 2:423-441.

Marchetti L, Klein M, Schlett K, Pfizenmaier K, Eisel UL (2004) Tumor necrosis factor (TNF)-mediated neuroprotection against glutamateinduced excitotoxicity is enhanced by $\mathrm{N}$-methyl-D-aspartate receptor activation. Essential role of a TNF receptor 2-mediated phosphatidylinositol 3-kinase-dependent NF-kappa B pathway. J Biol Chem 279:32869-32881.

Martin-Villalba A, Herr I, Jeremias I, Hahne M, Brandt R, Vogel J, Schenkel J, Herdegen T, Debatin KM (1999) CD95 ligand (Fas-L/APO-1L) and tumor necrosis factor-related apoptosis-inducing ligand mediate ischemiainduced apoptosis in neurons. J Neurosci 19:3809-3817.

Martin-Villalba A, Hahne M, Kleber S, Vogel J, Falk W, Schenkel J, Krammer $\mathrm{PH}$ (2001) Therapeutic neutralization of CD95-ligand and TNF attenuates brain damage in stroke. Cell Death Differ 8:679-686.

Mielke K, Herdegen T (2002) Fatal shift of signal transduction is an integral part of neuronal differentiation: JNKs realize TNFalpha-mediated apoptosis in neuronlike, but not naive, PC12 cells. Mol Cell Neurosci 20:211-224.

Mobley WC, Schenker A, Shooter EM (1976) Characterization and isolation of proteolytically modified nerve growth factor. Biochemistry 15:5543-5552. 
Nadeau S, Rivest S (1999) Regulation of the gene encoding tumor necrosis factor alpha (TNF-alpha) in the rat brain and pituitary in response in different models of systemic immune challenge. J Neuropathol Exp Neurol 58:61-77.

Naldini L, Blomer U, Gage FH, Trono D, Verma IM (1996) Efficient transfer, integration, and sustained long-term expression of the transgene in adult rat brains injected with a lentiviral vector. Proc Natl Acad Sci USA 93:11382-11388.

Neumann H, Schweigreiter R, Yamashita T, Rosenkranz K, Wekerle H, Barde YA (2002) Tumor necrosis factor inhibits neurite outgrowth and branching of hippocampal neurons by a $\rho$-dependent mechanism. J Neurosci 22:854-862.

Okano H, Shiraki K, Inoue H, Kawakita T, Yamanaka T, Deguchi M, Sugimoto K, Sakai T, Ohmori S, Fujikawa K, Murata K, Nakano T (2003) Cellular FLICE/caspase-8-inhibitory protein as a principal regulator of cell death and survival in human hepatocellular carcinoma. Lab Invest 83:1033-1043.

Park C, Sakamaki K, Tachibana O, Yamashima T, Yamashita J, Yonehara S (1998) Expression of fas antigen in the normal mouse brain. Biochem Biophys Res Commun 252:623-628.

Putcha GV, Harris CA, Moulder KL, Easton RM, Thompson CB, Johnson Jr EM (2002) Intrinsic and extrinsic pathway signaling during neuronal apoptosis: lessons from the analysis of mutant mice. J Cell Biol 157:441-453.

Raoul C, Henderson CE, Pettmann B (1999) Programmed cell death of embryonic motoneurons triggered through the Fas death receptor. J Cell Biol 147:1049-1062.

Raoul C, Pettmann B, Henderson CE (2000) Active killing of neurons during development and following stress: a role for p75(NTR) and Fas? Curr Opin Neurobiol 10:111-117.

Raoul C, Estevez AG, Nishimune H, Cleveland DW, deLapeyriere O, Henderson CE, Haase G, Pettmann B (2002) Motoneuron death triggered by a specific pathway downstream of Fas potentiation by ALS-linked SOD1 mutations. Neuron 35:1067-1083.

Raoul C, Buhler E, Sadeghi C, Jacquier A, Aebischer P, Pettmann B, Henderson CE, Haase G (2006) Chronic activation in presymptomatic amyotrophic lateral sclerosis (ALS) mice of a feedback loop involving Fas, Daxx, and FasL. Proc Natl Acad Sci USA 103:6007-6012.

Rickle A, Behbahani H, Ankarcrona M, Winblad B, Cowburn RF (2006) PTEN, Akt, and GSK3beta signalling in rat primary cortical neuronal cultures following tumor necrosis factor-alpha and trans-4-hydroxy-2nonenal treatments. J Neurosci Res 84:596-605.

Schneider TJ, Fischer GM, Donohoe TJ, Colarusso TP, Rothstein TL (1999) A novel gene coding for a Fas apoptosis inhibitory molecule (FAIM) isolated from inducibly Fas-resistant B lymphocytes. J Exp Med 189:949-956.

Schweitzer B, Suter U, Taylor V (2002) Neural membrane protein 35/Lifeguard is localized at postsynaptic sites and in dendrites. Brain Res Mol Brain Res 107:47-56.

Shin DH, Lee E, Kim HJ, Kim S, Cho SS, Chang KY, Lee WJ (2002) Fas ligand mRNA expression in the mouse central nervous system. J Neuroimmunol 123:50-57.

Sole C, Dolcet X, Segura MF, Gutierrez H, Diaz-Meco MT, Gozzelino R, Sanchis D, Bayascas JR, Gallego C, Moscat J, Davies AM, Comella JX (2004) The death receptor antagonist FAIM promotes neurite outgrowth by a mechanism that depends on ERK and NF-kappa B signaling. J Cell Biol 167:479-492.

Somia NV, Schmitt MJ, Vetter DE, Van Antwerp D, Heinemann SF, Verma IM (1999) LFG: an anti-apoptotic gene that provides protection from Fas-mediated cell death. Proc Natl Acad Sci USA 96:12667-12672.
Thome M, Schneider P, Hofmann K, Fickenscher H, Meinl E, Neipel F, Mattmann C, Burns K, Bodmer JL, Schroter M, Scaffidi C, Krammer PH, Peter ME, Tschopp J (1997) Viral FLICE-inhibitory proteins (FLIPs) prevent apoptosis induced by death receptors. Nature 386:517-521.

Tran SE, Holmstrom TH, Ahonen M, Kahari VM, Eriksson JE (2001) MAPK/ERK overrides the apoptotic signaling from Fas, TNF, and TRAIL receptors. J Biol Chem 276:16484-16490.

Tran SE, Meinander A, Eriksson JE (2004) Instant decisions: transcriptionindependent control of death-receptor-mediated apoptosis. Trends Biochem Sci 29:601-608.

Tschopp J, Irmler M, Thome M (1998) Inhibition of fas death signals by FLIPs. Curr Opin Immunol 10:552-558.

Tschopp J, Martinon F, Hofmann K (1999) Apoptosis: silencing the death receptors. Curr Biol 9:R381-R384.

Ugolini G, Raoul C, Ferri A, Haenggeli C, Yamamoto Y, Salaun D, Henderson CE, Kato AC, Pettmann B, Hueber AO (2003) Fas/tumor necrosis factor receptor death signaling is required for axotomy-induced death of motoneurons in vivo. J Neurosci 23:8526-8531.

Wen W, Sanelli T, Ge W, Strong W, Strong MJ (2006) Activated microglial supernatant induced motor neuron cytotoxicity is associated with upregulation of the TNFR1 receptor. Neurosci Res 55:87-95.

Wu S, Zhou L, Rose M, Xiao X, Graham SH (2004) c-FLIP-L recombinant adeno-associated virus vector infection prevents Fas-mediated but not nerve growth factor withdrawal-mediated cell death in PC12 cells. Brain Res Mol Brain Res 122:79-87.

Xiao CW, Yan X, Li Y, Reddy SA, Tsang BK (2003) Resistance of human ovarian cancer cells to tumor necrosis factor alpha is a consequence of nuclear factor kappaB-mediated induction of Fas-associated death domain-like interleukin-1beta-converting enzyme-like inhibitory protein. Endocrinology 144:623-630.

Yeh WC, Itie A, Elia AJ, Ng M, Shu HB, Wakeham A, Mirtsos C, Suzuki N, Bonnard M, Goeddel DV, Mak TW (2000) Requirement for Casper (cFLIP) in regulation of death receptor-induced apoptosis and embryonic development. Immunity 12:633-642.

Yoshino Q, Matsumo H, Nakamura H, Yudoh K, Abe Y, Sawai T, Uzuki M, Yonehara S, Kimura T (2004) The role of Fas-mediated apoptosis after traumatic spinal cord. Spine 29:1394-1404.

Yuste VJ, Bayascas JR, Llecha N, Sanchez-Lopez I, Boix J, Comella JX (2001) The absence of oligonucleosomal DNA fragmentation during apoptosis of IMR-5 neuroblastoma cells: disappearance of the caspase-activated DNase. J Biol Chem 276:22323-22331.

Yuste VJ, Sanchez-Lopez I, Sole C, Moubarak RS, Bayascas JR, Dolcet X, Encinas M, Susin SA, Comella JX (2005) The contribution of apoptosisinducing factor, caspase-activated DNase, and inhibitor of caspaseactivated DNase to the nuclear phenotype and DNA degradation during apoptosis. J Biol Chem 280:35670-35683.

Zhong X, Schneider TJ, Cabral DS, Donohoe TJ, Rothstein TL (2001) An alternatively spliced long form of Fas apoptosis inhibitory molecule (FAIM) with tissue-specific expression in the brain. Mol Immunol 38:65-72.

Zufferey R, Dull T, Mandel RJ, Bukovsky A, Quiroz D, Naldini L, Trono D (1998) Self-inactivating lentivirus vector for safe and efficient in vivo gene delivery. J Virol 72:9873-9880.

Zuliani C, Kleber S, Klussmann S, Wenger T, Kenzelmann M, Schreglmann N, Martinez A, del Rio JA, Soriano E, Vodrazka P, Kuner R, Groene HJ, Herr I, Krammer PH, Martin-Villalba A (2006) Control of neuronal branching by the death receptor CD95 (Fas/Apo-1). Cell Death Differ 13:31-40. 